\title{
Anesthetic Agents of Plant Origin: A Review of Phytochemicals with Anesthetic Activity
}

\author{
Hironori Tsuchiya \\ Department of Dental Basic Education, Asahi University School of Dentistry, 1851 Hozumi, Mizuho, \\ Gifu 501-0296, Japan; hiro@dent.asahi-u.ac.jp; Tel.: +81-58-329-1266
}

Received: 13 June 2017; Accepted: 17 August 2017; Published: 18 August 2017

\begin{abstract}
The majority of currently used anesthetic agents are derived from or associated with natural products, especially plants, as evidenced by cocaine that was isolated from coca (Erythroxylum coca, Erythroxylaceae) and became a prototype of modern local anesthetics and by thymol and eugenol contained in thyme (Thymus vulgaris, Lamiaceae) and clove (Syzygium aromaticum, Myrtaceae), respectively, both of which are structurally and mechanistically similar to intravenous phenolic anesthetics. This paper reviews different classes of phytochemicals with the anesthetic activity and their characteristic molecular structures that could be lead compounds for anesthetics and anesthesia-related drugs. Phytochemicals in research papers published between 1996 and 2016 were retrieved from the point of view of well-known modes of anesthetic action, that is, the mechanistic interactions with $\mathrm{Na}^{+}$channels, $\gamma$-aminobutyric acid type A receptors, $\mathrm{N}$-methyl-D-aspartate receptors and lipid membranes. The searched phytochemicals include terpenoids, alkaloids and flavonoids because they have been frequently reported to possess local anesthetic, general anesthetic, antinociceptive, analgesic or sedative property. Clinical applicability of phytochemicals to local and general anesthesia is discussed by referring to animal in vivo experiments and human pre-clinical trials. This review will give structural suggestions for novel anesthetic agents of plant origin.
\end{abstract}

Keywords: phytochemical; local anesthetic; general anesthetic; plant origin; pharmacological mechanism; lead compound

\section{Introduction}

Many of the currently used medicines originate from natural products, especially plants. Drugs and plants are closely related to each other through the use of traditional medicines or ethnomedicines that are mainly prepared from plants [1]. Representative drugs of plant origin include the anticholinergic atropine (from Atropa belladonna, Solanaceae), the antimalarial quinine (from Cinchona officinalis, Rubiaceae), the cardiotonic digitoxin (from Digitalis purpurea, Plantaginaceae), the antitussive codeine (from Papaver somniferum, Papaveraceae), and the analgesic salicylate and its derivative aspirin (from Salix alba, Salicaceae). Plants and herbs are the sources of not only crude drugs, but also bioactive compounds that could lead to novel drug structures [2].

Because medicinal plants and herbs have been used since ancient times for relieving pain caused by disease, injury and surgery, some of them contributed to the development of modern anesthesia [3]. Cocaine, the first local anesthetic, originates from a specific plant alkaloid and the widely used intravenous anesthetic propofol shares the partial structure and pharmacological mechanism with certain plant terpenoids. The anesthetic adjunct morphine and the injectable muscle relaxant $d$-tubocurarine were also derived from opium poppy and the arrow poison curare prepared with vine plants, respectively.

For discovering drug candidates, plants of interest are screened for the presence of bioactive components, phytochemicals responsible for the bioactivity are isolated, their molecular structures 
are identified, and then the original structures of phytochemicals may be semi-synthetically modified to enhance the activity or reduce the toxicity [4]. In particular, a research strategy based on the pharmacological mechanism is very effective to obtain phytochemical lead compounds for anesthetics and anesthesia-related drugs [5].

This paper reviews different classes of phytochemicals with the significant anesthetic activity and their characteristic molecular structures from the point of view of well-known modes of anesthetic action, that is, the mechanistic interactions with ion channels, receptors and lipid membranes. The review focuses on terpenoids, alkaloids and flavonoids because they have been frequently reported to possess local anesthetic, general anesthetic, antinociceptive, analgesic or sedative property. Besides these phytochemicals, plants are able to produce anesthetic ethylene and vinyl ether especially under stress [6]. Although these stress hormones were previously applied to inhalational anesthesia [7], they are infrequently used today due to toxicity and degradation during storage. Therefore, such phytochemical alkenes and ethers are not included in this review. Clinical applicability and implication of the relevant terpenoids, alkaloids and flavonoids are discussed by referring to animal in vivo experiments and human pre-clinical trials with them.

\section{Method}

The present review is based on published articles and information retrieved from PubMed/MEDLINE, ACS Publications and Google Scholar. Databases were searched from 1996 to 2016. The relevant research papers published in recognized international journals and on-line journals in English were preferred, but review articles of specific importance were also included, although non-English language citations were excluded. Published case reports and abstracts were used when their complete articles were not available. The searches were carried out by using the following terms or combinations thereof: "local anesthetic", "general anesthetic", "antinociceptive", "analgesic" and "sedative" for pharmacological activity; "plant component", "terpenoid", "alkaloid" and "flavonoid" for phytochemicals; and " $\mathrm{Na}^{+}$channel", " $\gamma$-aminobutyric acid type A (GABA $)$ receptor", "N-methyl-D-aspartate (NMDA) receptor" and "membrane interaction" for molecular mechanisms. Collected articles were reviewed by title, abstract and text for relevance, with preference to more recent publications. Their bibliographies were also searched for additional references.

\section{Plants That Contributed to the Development of Anesthesia}

\subsection{Local Anesthetics Derived from Plant Alkaloid}

The earliest use and cultivation of coca, a shrub of the genus Erythroxylum, in the Andean region of South America, are very likely to date back to several thousand years B.C. [8]. However, a pain-relieving substance had been neither structurally identified nor clinically applied until the leaves of Erythroxylum coca (Erythroxylaceae) were taken from Peru to Europe. In 1860, Albert Niemann in Göttingen reported that chewing coca leaves took away tongue feeling and taste. He isolated an active substance from them and named it as "cocaine". Sigmund Freud, the founder of psychoanalysis, read Niemann's report and considered using cocaine to overcome morphine addiction. He encouraged his colleague Carl Koller, a resident in ophthalmology in Vienna, to take part in the study of cocaine. Koller experimented on animals and humans by dropping a cocaine solution onto the eyeballs and found the numbing effect of cocaine on the eye. Shortly thereafter, he successfully performed cataract surgery using cocaine as a topical anesthetic in 1884 [9]. After his first clinical introduction, modern local anesthesia began with the development of injectable cocaine and its use for spinal anesthesia. In 1898, Richard Willstätter structurally identified cocaine as methyl $(1 R, 2 R, 3 S, 5 S)$-3-(benzoyloxy)-8-methyl-8-azabicyclo[3.2.1] octane-2-carboxylate (Figure 1). However, as undesirable (toxicity and addiction) and problematic (short duration and difficult sterilization) properties of cocaine became apparent, its molecular structure was modified to obtain safer and more effective drugs. In 1904, Alfred Einhorn synthesized procaine to replace cocaine, followed 
by a series of synthetic drugs: tetracaine, lidocaine, 2-chloroprocaine, bupivacaine, mepivacaine, prilocaine, etidocaine, ropivacaine and levobupivacaine (Figure 1). Local anesthetics derived from plant alkaloid cocaine, especially amide-type drugs, have been successfully used in a wide range of situations to relieve and control pain. The most widely recognized mode of action for local anesthetics is the interaction with voltage-gated $\mathrm{Na}^{+}$channels to inhibit sensory and motor functions [10]. Anesthetic molecules penetrate through the lipid barriers of nerve sheaths and diffuse across the lipid bilayers of cell membranes so that they access the intracellular or cell-interior binding sites on $\mathrm{Na}^{+}$channels embedded in membranes. Local anesthetics also diffuse into lipid bilayers and act on membrane-constituting lipids, modifying the physicochemical properties of neuronal and cardiomyocyte membranes [11].

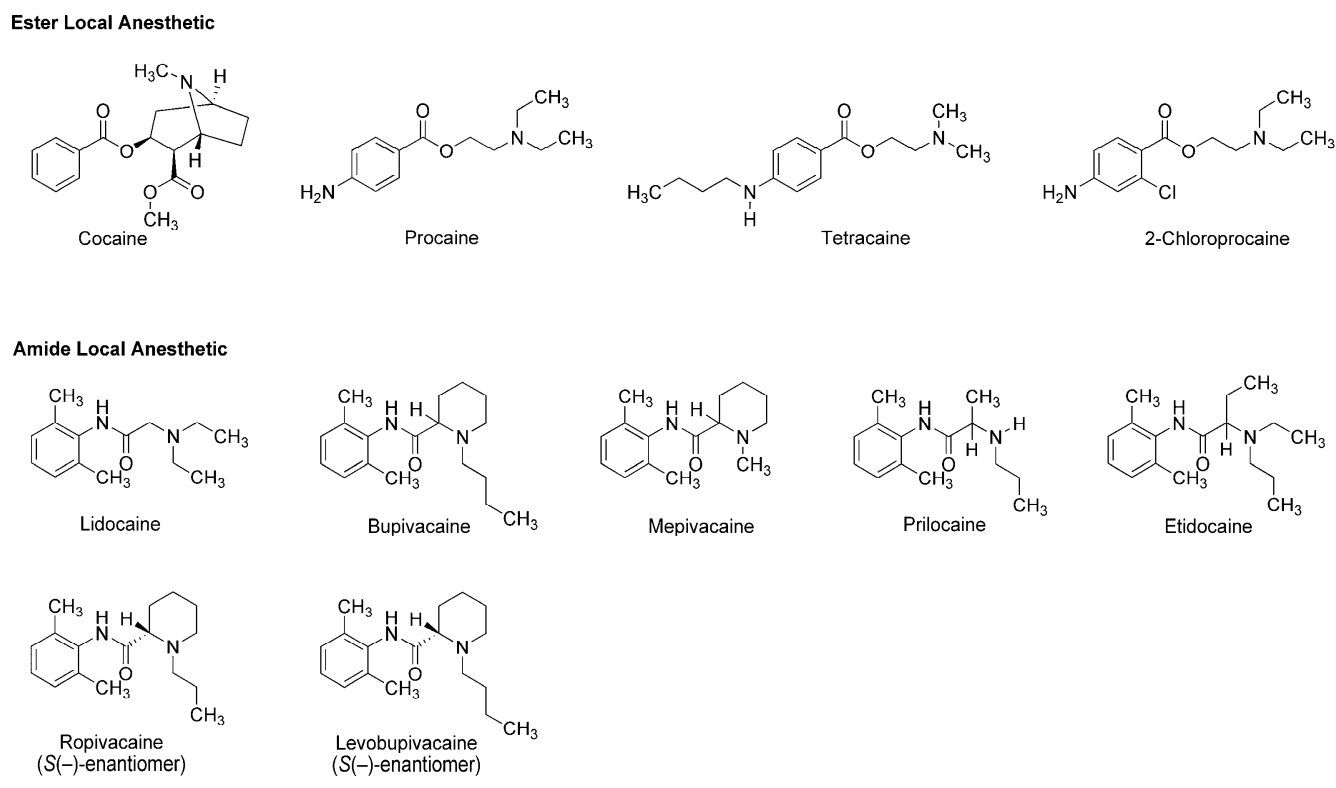

Figure 1. Local anesthetics derived from the plant alkaloid cocaine.

\subsection{General Anesthetics Associated with Plant Terpenoids}

Thymol (2-isopropyl-5-methylphenol) and eugenol (4-allyl-2-methoxyphenol) (Figure 2) are contained in thyme (Thymus vulgaris, Lamiaceae) and clove (Syzygium aromaticum, Myrtaceae), respectively, both of which are well-known for culinary and medicinal uses. Eugenol also occurs in herbs such as nutmeg (Myristica fragrans, Myristicaceae), cinnamon (Cinnamomum verum, Lauraceae) and basil (Ocimum basilicum, Lamiaceae). Because these terpenoid phenols possess antinociceptive and antibacterial effects, they have been extensively used in dental practice as a sedative or analgesic agent for pulpitis, toothache and dental hyperalgesia. In addition, thymol, eugenol and their structurally-related compounds exhibit general anesthetic activity.

In the 1950s, the utility as a general anesthetic was discovered in eugenol derivatives such as eunal (acetamidoeugenol or 2-(4-allyl-2-methoxyphenoxy)- $N, N$-diethylacetamide), propinal (N,N-diethyl-2-(2-methoxy-4-propylphenoxy)acetamide) and propanidid (propyl [4-[( $N, N$-diethyl -carbamoyl)methoxy]-3-methoxyphenyl]acetate) (Figure 2). Although propanidid was first used as an ultra-short-acting anesthesia-inducing agent for short minor operations, it was withdrawn because of the anaphylactic reaction when given intravenously and orally. James and Glen [12] synthesized a series of alkylphenols including thymol and its structural analogs to determine the structure and anesthetic activity relationship, which indicated that diisopropyl phenol derivatives are promising as an intravenous anesthetic. Among them, propofol (2,6-diisopropylphenol) (Figure 2) was revealed to have desirable clinical features [13]. In 1977, propofol was subjected to clinical trials as a short-acting intravenous agent to induce and maintain general anesthesia, and thereafter it largely replaced 
thiopental. Propofol is not only structurally related to plant terpenoids but it also allosterically positively modulates $\mathrm{GABA}_{\mathrm{A}}$ receptors like thymol [14] and eugenol [15]. Propofol, thymol and eugenol also interact mechanistically with lipid membranes to modify the physicochemical properties of biological and biomimetic membranes in a structure-dependent manner [16,17].

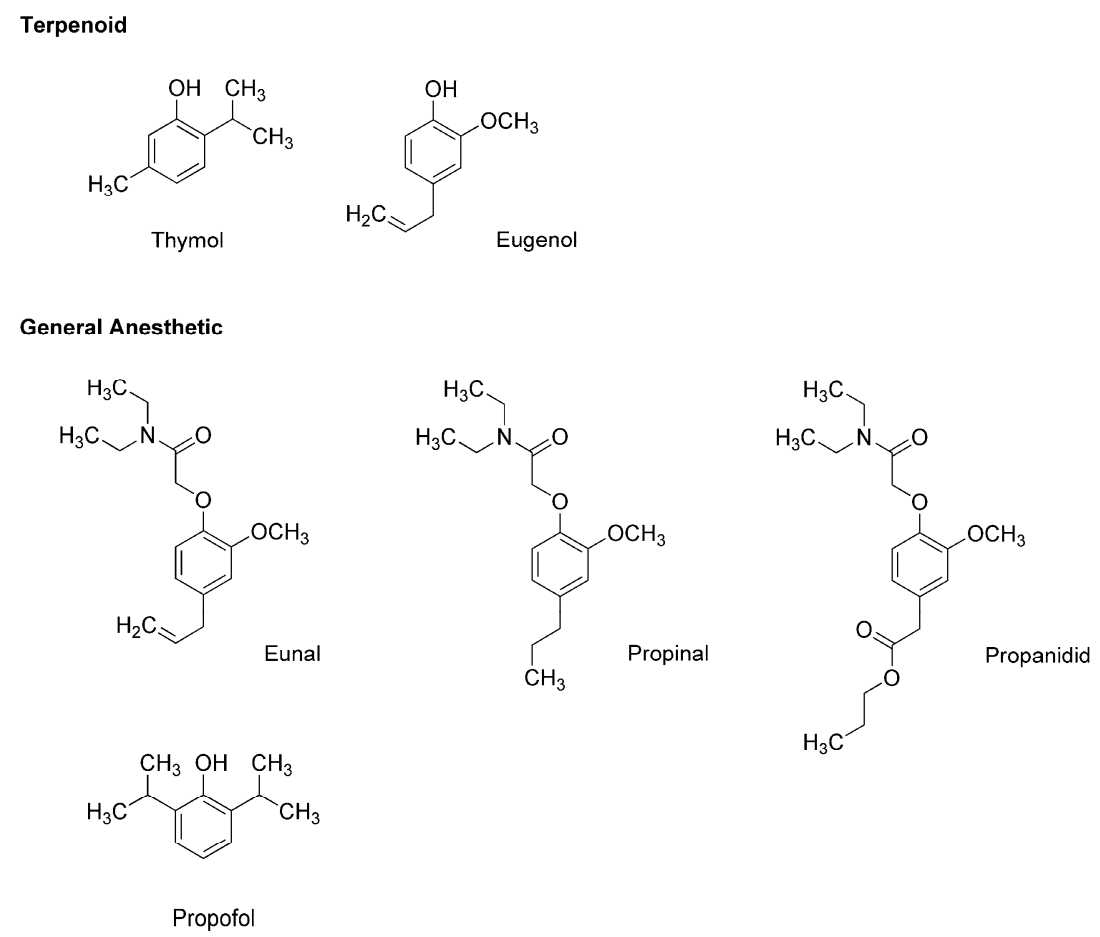

Figure 2. General anesthetics associated with plant terpenoid thymol and eugenol.

\section{Phytochemicals with the Local Anesthetic Activity}

Local anesthetics reversibly block voltage-gated (voltage-dependent or voltage-sensitive) $\mathrm{Na}^{+}$ channels (Nav channels) that are responsible for the initiation and propagation of action potentials of excitable cells in the peripheral nervous system and the cardiac system [10]. Voltage-gated $\mathrm{Na}^{+}$channels are integral membrane proteins that are composed of a core $\alpha$-subunit associated with one or more regulatory $\beta$-subunits $(\beta 1, \beta 2, \beta 3$ and $\beta 4)$. The $\alpha$-subunit not only forms the pore selectively permeable for $\mathrm{Na}^{+}$ions but also contains the binding or receptor site for local anesthetics, anti-arrhythmic drugs and several neurotoxins. Local anesthetics bind to such a site and cause occlusion of the pore, resulting in the blockade of $\mathrm{Na}^{+}$channels. At least nine distinct $\alpha$-subunits (Nav1.1 to Nav1.9) have been cloned from mammalian $\mathrm{Na}^{+}$channels. Nav1.7, Nav1.8 and Nav1.9 are the channel isoforms of nociceptive neurons in the peripheral nervous system, and Nav1.1, Nav1.2, Nav1.3 and Nav1.6 are the isoforms in the central nervous system, whereas Nav1.4 and Nav1.5 are in skeletal muscle and heart, respectively [18]. Since Nav1.7 and Nav1.8 isoforms play a crucial role in pain transmission, both channels are implicated as the targets for anesthetic and analgesic drugs. Based on their affinity for neurotoxin tetrodotoxin (TTX), $\mathrm{Na}^{+}$channel subtypes are divided into TTX-sensitive voltage-gated $\mathrm{Na}^{+}$channels (including Nav1.1, Nav1.2, Nav1.3, Nav1.4, Nav1.6 and Nav1.7) and TTX-resistant voltage-gated $\mathrm{Na}^{+}$channels (including Nav1.5, Nav1.8 and Nav1.9), in which Nav1.8 and Nav1.9 are predominantly found in dorsal root ganglion neurons. While specific blockade of single or selected $\mathrm{Na}^{+}$channel subtypes in sensory neurons is considered to induce local anesthesia with less adverse effects, conventional local anesthetics and anti-arrhythmic drugs act on different $\mathrm{Na}^{+}$channel isoforms.

Local anesthetics introduced to clinical practice have a basic structure consisting of a lipophilic aromatic group, a positively chargeable amino terminus and an intermediate chain. In extracellular fluids, their molecules exhibit equilibrium between uncharged and charged forms, which is determined 
by the $\mathrm{pKa}$ of drugs and the $\mathrm{pH}$ of media. Once local anesthetics diffuse across membrane lipid bilayers, they re-exhibit equilibrium between uncharged and charged forms in intracellular fluids of cytoplasm. Their charged molecules exclusively interact with the receptor sites of $\mathrm{Na}^{+}$channels. In addition to membrane-embedded channel proteins, local anesthetics structure-specifically act on membrane-constituting lipids, directly depressing the functions of neuronal membranes and indirectly inhibiting the activity of $\mathrm{Na}^{+}$channels by modifying the physicochemical properties (fluidity, order, microviscosity or elasticity) of lipid membranes surrounding channel proteins [11]. Since plant terpenoids, alkaloids and flavonoids have amphiphilic structures as well as local anesthetics, these phytochemicals are expected to affect the activity of voltage-gated $\mathrm{Na}^{+}$channels through the common mechanisms.

\subsection{Plant Preparations}

Chewing Piper betel (Piperaceae) leaves, called betel in southern India and Malaysia, is known to numb the mouth and dull the taste. Krishnakumar et al., [19] investigated the local anesthetic activity of this plant by an intradermal wheal assay using guinea pigs and a corneal reflex test using rabbits. The plain extracts from betel leaves showed both infiltration and surface anesthetic effects that were almost comparable to those of lidocaine.

The fruit tree Vitex doniana (Verbenaceae) growing in an African savanna is used for treating chronic cutaneous wounds. Abdulrahman et al., [20] prepared aqueous extracts from its root bark by a Soxhlet extraction method and examined their effects on the peripheral nervous system of rabbits by an intradermal wheal assay. Injecting extracts of $25 \mathrm{mg} / \mathrm{mL}$ and $100 \mathrm{mg} / \mathrm{mL}$ produced $55.6 \%$ and $80.6 \%$ local anesthesia, respectively, although they were less effective than lidocaine of $0.3 \mathrm{mg} / \mathrm{mL}$ and $1.0 \mathrm{mg} / \mathrm{mL}$ (i.d.). In their following study [21], 95\% $(v / v)$ ethanol extracts from the stem bark of Vitex doniana produced $70 \%$ and $80 \%$ local anesthesia at $50 \mathrm{mg} / \mathrm{mL}$ and $100 \mathrm{mg} / \mathrm{mL}$ (i.d.), respectively. The ethanol extracts also exhibited the significant antinociceptive activity against acetic acid-induced writhing and thermally-induced pain in mice.

Spilathes acmella (Asteraceae), an herb growing throughout the tropics, is used for rheumatism, sore throat and toothache. Eating its leaves and flowers is known to numb the tongue. Chakraborty et al., [22] tested the local anesthetic activity of Spilathes acmella by an intracutaneous wheal assay. They injected a $0.2 \mathrm{~mL}$-volume of aqueous extracts obtained from its aerial parts to the backs of guinea pigs and observed the responses of wheal areas to pin prick. Injections of $10 \%$ and $20 \%$ extracts produced $70 \%$ and $87 \%$ local anesthesia, respectively, while $2 \%$ lidocaine showed $97 \%$ local anesthesia.

Karaya gum or sterculia gum from the trunk of Sterculia tragacantha (Malvaceae), a deciduous shrub in tropical Africa, is used for treating burns. Udegbunam et al., [23] prepared $80 \%(v / v)$ methanol extracts from Sterculia tragacantha leaves to verify the anesthetic activity by an intradermal wheel test using guinea pigs. Injections at $0.03 \mathrm{mg} / \mathrm{mL}$ and $10 \mathrm{mg} / \mathrm{mL}$ produced $86 \%$ and $100 \%$ local anesthesia, respectively, compared with $69 \%$ and $94 \%$ local anesthesia induced by lidocaine of $0.03 \mathrm{mg} / \mathrm{mL}$ and $0.1 \mathrm{mg} / \mathrm{mL}$. They fractionated the active extracts by silica-gel chromatography and indicated that alkaloid and saponin components are responsible for local anesthetic effects. They also reported that the subcutaneous injection of Sterculia tragacantha methanol extracts induced local anesthesia in goats [24].

\subsection{Essential Oils and Terpenoids}

Essential oils, the concentrated liquids of a highly complex mixture of volatile phytochemicals, are generally extracted from aromatic plants, including citrus peel and caraway. In addition to the utility as perfume and flavor, the medicinal property has been suggested for essential oils from peppermint, lavender, eucalyptus, rosemary, thyme, nutmeg and chamomile. Terpenoids occupy more than $90 \%$ of phytochemicals contained in the essential oils. Their structures consisting of five-carbon (C5) isoprene units are classified by the number of $\mathrm{C} 5$ unit into monoterpenoids with $2 \times \mathrm{C} 5$ unit, sesquiterpenoids with $3 \times \mathrm{C} 5$ unit, diterpenoids with $4 \times \mathrm{C} 5$ unit and triterpenoids with $6 \times \mathrm{C} 5$ unit. Monoterpenoids 
are composed of acyclic (open-chain), monocyclic and bicyclic structures. Excellent reviews were recently published for the pharmacological effects of essential oils and their component terpenoids by de Sousa [25] and Guimarães et al., [26], and for the therapeutic benefits of essential oils by Djilani and Dicko [27].

A variety of monoterpenoids have been suggested to modulate the activity of voltage- and ligand-gated ion channels [28]. Zalachoras et al., [29] determined the conduction changes of frog sciatic nerve fibers to compare the local anesthetic activity of five monoterpenes: acyclic linalool, monocyclic $p$-cymene, and bicyclic eucalyptol (1,8-cineol), $\alpha$-pinene and fenchone (Figure 3$)$. They placed the isolated nerves in a three-chambered recording bath and monitored compound action potentials (CAPs). Their results indicated that 7.5-30 mM linalool and $30 \mathrm{mM}$ fenchone exert local anesthetic effects as well as 3.5-30 mM lidocaine, while the effects of eucalyptol, $\alpha$-pinene and $p$-cymene were minor.

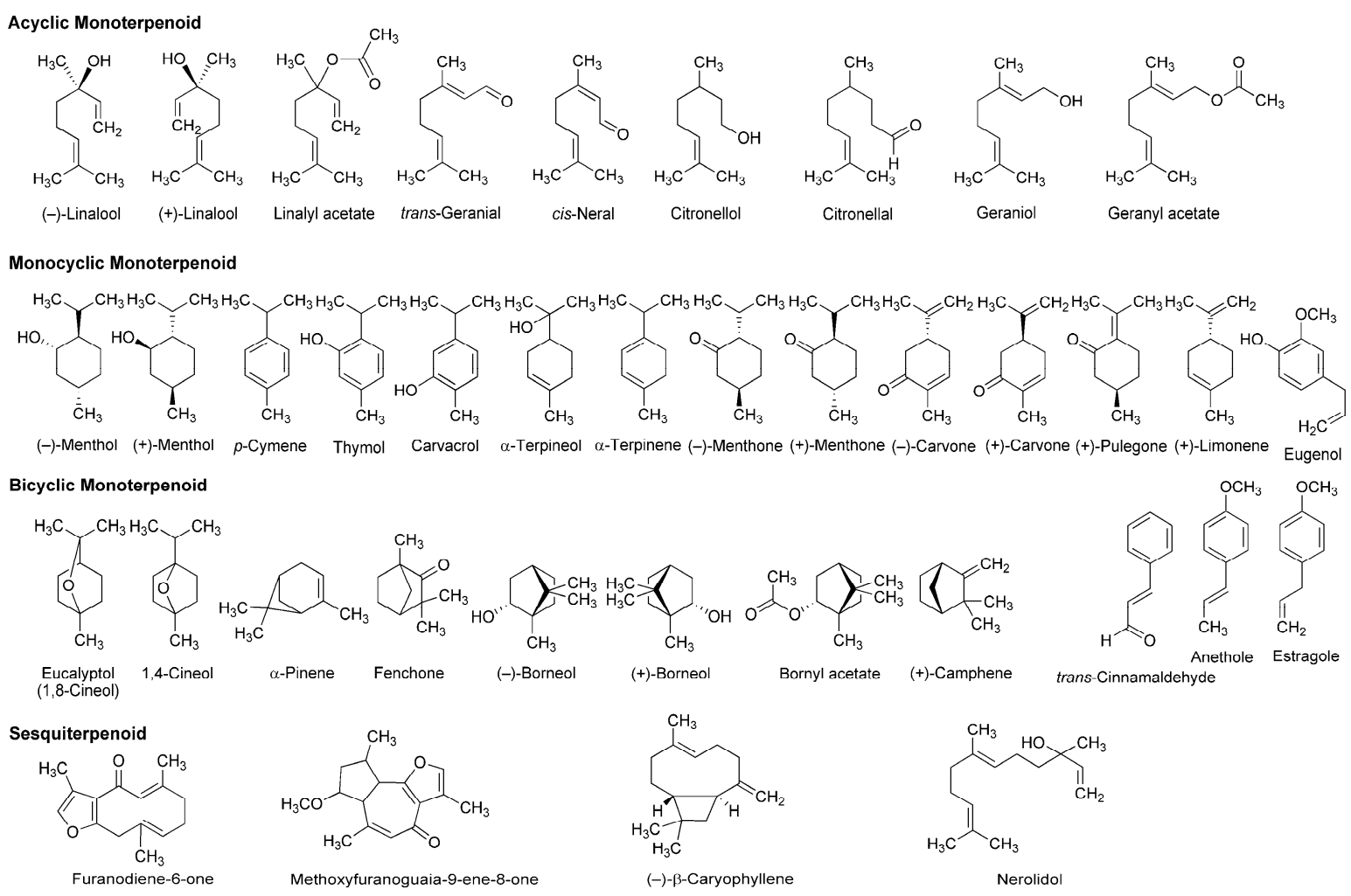

Figure 3. Terpenoids with local anesthetic activity.

Lavender (Lavandula angustifolia, Lamiaceae) has been traditionally used as a medicinal herb with relaxant and antispasmodic activity. Ghelardini et al., [30] showed that lavender essential oil and its major components linalool and linalyl acetate (Figure 3) reduce the electrically evoked contractions of rat phrenic-hemidiaphragm at $0.1 \mu \mathrm{g} / \mathrm{mL}$ to $1 \mathrm{mg} / \mathrm{mL}$ as well as procaine and lidocaine. In their following experiments, lavender essential oil, linalool and linalyl acetate depressed rabbit conjunctival reflexes by administrating $0.03-2.5 \mathrm{mg} / \mathrm{mL}$ in the conjunctival sac. Such effects were evident $5 \mathrm{~min}$ after $2.5 \mathrm{mg} / \mathrm{mL}$ administration and diminished within $15 \mathrm{~min}$. Leal-Cardoso et al., [31] revealed that linalool reversely blocks the excitability of rat sciatic nerves and inhibits the voltage-gated $\mathrm{Na}^{+}$currents of rat dorsal root ganglion neurons at sub-micromolar concentrations. Linalool exists as (-)-enantiomer or (+)-enantiomer in essential oils because it has a chiral center at the 3-position (Figure 3). (-)-Linalool predominantly occurs in essential oils from lavender, laurel (Laurus nobilis, Lauraceae) and basil (Ocimum basilicum, Lamiaceae), but (+)-linalool in ones from coriander (Coriandrum sativum, Apiaceae). Peana et al., [32] reported the comparative anti-inflammatory effects of (-)-enantiomer, racemate 
and acetyl ester of linalool. In a carrageenan-induced hind paw edema model of rats, $(-)$-linalool (25-75 mg/kg, s.c.) reduced the edemas more effectively than racemic linalool and linalyl acetate.

Monocyclic monoterpene menthol is contained in essential oils from peppermint (Mentha piperita, Lamiaceae) and spearmint (Mentha spicata, Lamiaceae) that are used for aromatherapy, mouthwash, toothpaste and topical preparations to relieve irritation and inflammation. Among eight stereoisomers, menthol naturally occurs as a (-)-enantiomer of the $1 R, 2 S, 5 R$ configuration (Figure 3). Galeotti et al., [33] comparatively evaluated the local anesthetic activity of (-)-menthol and $(+)$-menthol and their structural analog thymol and (-)-menthone (oxidized menthol). (-)-Menthol and (+)-menthol reduced the electrically evoked contractions of rat phrenic nerve-hemidiaphragm at $0.1-100 \mathrm{ng} / \mathrm{mL}$ as well as procaine, although thymol and (-)-menthone were not effective even at $1 \mu \mathrm{g} / \mathrm{mL}$. When applied to the rabbit conjunctival sac at 30-300 $\mu \mathrm{g} / \mathrm{mL},(-)$-menthol and (+)-menthol increased the number of stimuli necessary to provoke the reflex, but neither thymol nor $(-)$-menthone. Both menthol enantiomers produced these effects 5 min after treatments. Gaudioso et al., [34] studied the effects of micromolar menthol on different $\mathrm{Na}^{+}$channel subtypes of rat dorsal root ganglion neurons by a patch clamp method. They indicated that menthol inhibits TTX-resistant Nav1.8 and Nav1.9 and TTX-sensitive $\mathrm{Na}^{+}$channels in a concentration-, voltage- and frequency-dependent manner. Pan et al., [35] examined the action of menthol on pain hypersensitivity induced by inflammation. Their results suggested that menthol is a nonselective analgesic to act on both peripheral and central pain targets.

Kumamoto et al., [36-38] carried out a series of studies to compare the effects of various monoterpenoids on nerve conduction and transient receptor potential channels by recording CAPs in frog sciatic nerves. Acyclic citral (a mixture of trans-geranial and cis-neral), citronellol, citronellal, (-)-linalool, racemic linalool and geraniol; monocyclic (-)-menthol, (+)-menthol, thymol, carvacrol (thymol isomer), $\alpha$-terpineol, $(-)$-menthone, $(+)$-menthone, $(-)$-carvone, $(+)$-carvone and $(+)$-pulegone; terpenoid phenol eugenol; bicyclic (-)-borneol, (+)-borneol, eucalyptol (1,8-cineol) and 1,4-cineol; and terpenoid ester linalyl acetate, geranyl acetate and bornyl acetate (Figure 3) reduced CAP peak amplitudes with $\mathrm{IC}_{50}$ values of $0.34-7.2 \mathrm{mM}$. These monoterpenoids also inhibited nerve conduction by blocking TTX-sensitive voltage-gated $\mathrm{Na}^{+}$channels involved in CAP production, but not activating transient receptor potential channels. The inhibition of CAPs was greatest in carvacrol and thymol, followed by citronellol, bornyl acetate and citral. In the structure and activity relationship, the CAP-inhibitory potency generally varied in the order of being phenols (carvacrol, thymol and eugenol) $\geq$ aldehydes (citral and citronellal) $\geq$ esters (bornyl acetate, geranyl acetate and linalyl acetate) $\geq$ alcohols (citronellol, geraniol, (+)-menthol, (-)-menthol, (+)-borneol, racemic linalool, (-)-borneol, $(-)$-linalool and $\alpha$-terpineol $) \geq$ ketones $((+)$-pulegone, $(-)$-carvone, $(-)$-menthone, $(+)$-carvone and (+)-menthone) > bicyclic monoterpenes (eucalyptol and 1,4-cineol). When comparing $\mathrm{IC}_{50}$ values (0.34-0.93 $\mathrm{mM})$ to reduce CAP peak amplitudes in frog sciatic nerves, the local anesthetic effects of carvacrol, thymol, citronellol, bornyl acetate, citral, citronellal, geranyl acetate, geraniol, linalyl acetate and (+)-menthol were almost equivalent to those of levobupivacaine, ropivacaine, lidocaine and cocaine [39-41].

In in vitro experiments of Joca et al., [42] using rat nerve samples, carvacrol reversely blocked the excitability of sciatic nerves with an $\mathrm{IC}_{50}$ value of $0.5 \mathrm{mM}$ and reduced the voltage-gated $\mathrm{Na}^{+}$currents of dorsal root ganglion neurons with an $\mathrm{IC}_{50}$ value of $0.37 \mathrm{mM}$. Cavalcante Melo et al., [43] confirmed its in vivo effects on mice. Carvacrol (50-100 mg/kg, p.o.) significantly inhibited nociception in acetic acid-induced abdominal constriction, formalin injection and hot plate tests. Such effects were not reversed by naloxone and L-arginine, indicating that neither the opioid system nor the nitric oxide pathway is responsible for antinociception by carvacrol. Gonçalves et al., [44] reported that (-)-carvone reduced the excitability of rat sciatic nerves at $10 \mathrm{mM}$ to block about 50\% CAP and that (-)-carvone (100-200 mg/kg, i.p.) was effective in inhibiting acetic acid-induced writhing and formalin-induced hind paw nociception of mice. 
Leal-Cardoso and his colleagues [45-50] performed a series of in vitro experiments using nerve samples from rats to determine the local anesthetic activity of monoterpenoid components in Croton nepetaefolius (Euphorbiaceae), Ocimum basilicum (Lamiaceae) and Ravensara anisata (Lauraceae). These plants used in folk medicine are rich in essential oils containing estragole and anethole (Figure 3). Both monocyclic monoterpenes directly inhibited $\mathrm{Na}^{+}$channels and blocked the excitability of peripheral nerves. Estragole inhibited total $\mathrm{Na}^{+}$currents and TTX-resistant $\mathrm{Na}^{+}$currents in dorsal root ganglion neurons with $\mathrm{IC}_{50}$ values of 3.2 and $3.6 \mathrm{mM}$, respectively, suggesting that it affects the excitability of peripheral nerves as well as local anesthetics [46]. Among monoterpenoids contained in Lippia alba (Verbenaceae) and Croton nepetaefolius (Euphorbiaceae), citral inhibited CAPs in sciatic nerves with an $\mathrm{IC}_{50}$ value of $0.23 \mathrm{mM}$ [48]. Eucalyptol reversely blocked the excitability of sciatic nerves and superior cervical ganglion neurons by acting on $\mathrm{Na}^{+}$channels directly $[49,50]$.

Ghelardini et al., [51] compared the local anesthetic activity of components in essential oils from medicinal herb marjoram (Origanum majorana, Lamiaceae) and anise (Pimpinella anisum, Apiaceae) by in vitro and in vivo experiments. $\alpha$-Terpineol and anethole reduced the electrically evoked contractions of rat phrenic nerve-hemidiaphragm at $0.001-1 \mu \mathrm{g} / \mathrm{mL}$ in a concentration-dependent manner, but not citronellal, (-)-carvone, (+)-carvone, $\alpha$-terpinene, eugenol and trans-cinnamaldehyde (Figure 3). Both active monoterpenes also increased the number of stimuli required to evoke rabbit conjunctival reflex at 10-100 $\mu \mathrm{g} / \mathrm{mL}$. Quintans-Júnior et al., [52] examined in vivo effects of several monoterpenes by acetic acid-induced writhing and formalin-injected hind paw licking tests using mice. para-Cymene (50-200 $\mathrm{mg} / \mathrm{kg}$, i.p.) showed the greatest antinociceptive effect in both tests, followed by acyclic geranyl acetate and bicyclic (+)-camphene (Figure 3).

Myrrh, a resin secreted by plants of the genus Commiphora (Burseraceae), has traditionally been used for treating wounds and toothache. Dolara et al., [53] chromatographed the extracts from Commiphora molmol to specify one fraction $(280 \mu \mathrm{g} / \mathrm{mL})$ with about a half anesthetic potency of $1 \%$ procaine by a rabbit conjunctival reflex test. They isolated two phytochemicals from the active fraction and identified them as furanodiene-6-one and methoxyfuranoguaia-9-ene-8-one (Figure 3). Both sesquiterpenes selectively and reversibly blocked $\mathrm{Na}^{+}$channels in an electrophysiological experiment using rat cardiac myocytes.

The bicyclic sesquiterpene (-)- $\beta$-caryophyllene (Figure 3) naturally occurs in essential oils from clove (Syzygium aromaticum, Myrtaceae), hop (Humulus lupulus, Cannabaceae), wild sweet basil (Ocimum campechianum, Lamiaceae) and oregano (Origanum vulgare, Lamiaceae). Ghelardini et al., [54] reported that $\beta$-caryophyllene exerted in vitro and in vivo local anesthetic effects comparable to those of procaine. Beta-caryophyllene reduced the electrically evoked contractions of rat phrenic nerve-hemidiaphragm at $0.1 \mathrm{ng} / \mathrm{mL}$ to $1.0 \mu \mathrm{g} / \mathrm{mL}$ and increased the number of stimuli necessary to provoke rabbit conjunctival reflex at $10 \mu \mathrm{g} / \mathrm{mL}$ to $1.0 \mathrm{mg} / \mathrm{mL}$.

As one of pharmacological mechanisms for terpenoids, Mendanha et al., [55] investigated the interaction with biological membranes by electron paramagnetic resonance spectroscopy. All the tested nerolidol, menthol, pulegone, carvone, (+)-limonene, $\alpha$-terpineol and eucalyptol (Figure 3) mechanistically interacted with mouse fibroblast and human erythrocyte membranes to increase their fluidity with the potency being sesquiterpene nerolidol greater than other monoterpenoids. Yin et al., [56] and Nowotarska et al., [57] revealed that bicyclic borneol and monocyclic carvacrol act on phospholipid bilayers to cause membrane fluidization as well as geraniol. Reiner et al., [17] verified the interactivity of thymol, eugenol and carvacrol with egg phosphatidylcholine unilamellar vesicles by ${ }^{1} \mathrm{H}$-nuclear magnetic resonance spectroscopy. Their results indicated that these monoterpenoids are inserted into lipid bilayers to locate in the region between the choline polar group, the glycerol and the first atoms of the acyl chains. Tsuchiya and Mizogami [58] characterized the membrane effects of terpenoid phenols that increase the fluidity of neuro-mimetic membranes at $1-10 \mu \mathrm{M}$ with the relative potency being thymol > carvacrol $>$ eugenol as well as $50-200 \mu \mathrm{M}$ bupivacaine and lidocaine. These phytochemicals penetrated into lipid bilayers with preference to the deeper hydrophobic region of membranes. Thymol and eugenol achieve the concentrations of $10-100 \mu \mathrm{M}$ in dental pulps and 
dentins adjacent to the pulp space. Since both terpenoids show local anesthetic and analgesic effects at such micromolar concentrations together with acting on neuronal membranes, they are frequently applied to clinical dentistry as a sedative for toothache, pulpitis and dental hyperalgesia.

Sarmento-Neto et al., [59] recently published a review that focused on the antinociceptive potentials of essential oils from 31 plant species and their major component terpenoids.

\subsection{Alkaloids}

Unlike conventional local anesthetics to act on $\mathrm{Na}^{+}, \mathrm{K}^{+}$and $\mathrm{Ca}^{2+}$ channels, neurotoxins specifically block voltage-gated $\mathrm{Na}^{+}$channels [60], so they should be an ideal local anesthetic. Natural neurotoxins, many of which belong to plant alkaloids, potentially produce long-duration local anesthesia. Some alkaloids isolated from plants of the genera Aconitum and Delphinium have been applied as analgesic and anti-inflammatory agents in Chinese medicine.

Dzhakhangirov et al., [61] investigated the surface and infiltration anesthetic effects of Aconitum and Delphinium alkaloids by a rabbit corneal reflex test to drop sample solutions $(0.01-1 \%)$ into the conjunctival sac and by a cat neck trunk anesthesia method to inject $0.1 \mathrm{~mL}$ sample solutions $(0.1-0.5 \%)$ intracutaneously and subcutaneously. Lappaconitine, sepaconitine, ranaconitine, septephine, artecorine, 6-O-benzoylheteratisine and tadzhaconine (Figure 4) showed greater potency and longer duration of anesthesia than procaine and lidocaine.

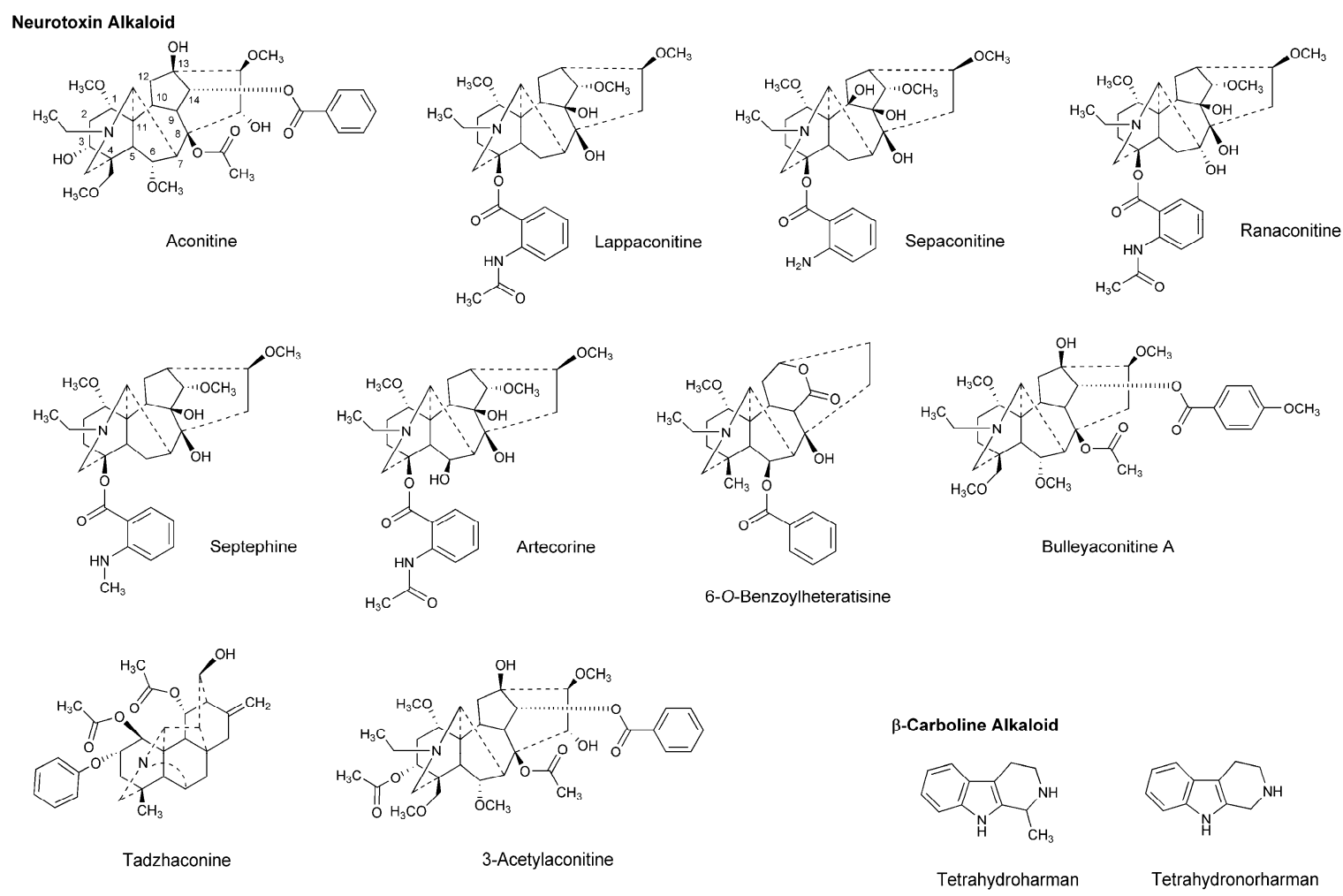

Figure 4. Alkaloids with local anesthetic activity.

At least six receptor sites on voltage-gated $\mathrm{Na}^{+}$channels have been identified for neurotoxin alkaloids. Plant alkaloid aconitine, lappaconitine and bulleyaconitine A (Figure 4) bind to the receptor site 2 to block $\mathrm{Na}^{+}$conduction, whereas pufferfish toxin TTX and shellfish toxin saxitoxin, to the receptor site 1 . Site 2 neurotoxins and local anesthetics have overlapping but non-identical binding regions [62]. The most abundant neurotoxins in Aconitum and Delphinium plants are aconitine-like alkaloids that activate $\mathrm{Na}^{+}$channels and shift a conformational equilibrium toward the activated state, whereas the other alkaloids block voltage-gated $\mathrm{Na}^{+}$channels. Despite the structural 
similarity, aconitine activates voltage-gated $\mathrm{Na}^{+}$channels, but lappaconitine blocks. The structure and activity relationship indicates that alkaloids with a benzoyl ester side chain at the 14-position and at the 4-position act as an agonist and a blocker of voltage-gated $\mathrm{Na}^{+}$channels, respectively.

Gutser et al., [63] compared the local anesthetic effects of Aconitum alkaloids. They intravenously administered alkaloid samples to mice and after $5 \mathrm{~min}$, injected $5 \%$ formaldehyde $(20 \mu \mathrm{L}$, s.c.) to induce hyperalgesia, followed by monitoring nociception-related behaviors during the subsequent $30 \mathrm{~min}$. Antinociceptive $\mathrm{ED}_{50}$ values in the early phase (0-15 $\mathrm{min}$ ) and the late phase (15-30 $\left.\mathrm{min}\right)$ were $0.028 \mathrm{mg} / \mathrm{kg}$ and $0.027 \mathrm{mg} / \mathrm{kg}$ for aconitine and $0.097 \mathrm{mg} / \mathrm{kg}$ and $0.077 \mathrm{mg} / \mathrm{kg}$ for 3-acetylaconitine. Both alkaloids showed high affinity for the site 2 of rat synaptosomal $\mathrm{Na}^{+}$channels. In contrast, lappaconitine was less effective to show antinociceptive $E_{50}$ values of $2.7 \mathrm{mg} / \mathrm{kg}$ and $2.9 \mathrm{mg} / \mathrm{kg}$ in the early phase and the late phase, respectively. Aconitine and 3-acetylaconitine are speculated to inhibit neuronal conduction by persistent depolarization, whereas lappaconitine, to block $\mathrm{Na}^{+}$ channels like local anesthetics. Wang et al., [64] reported analgesic and anti-inflammatory effects of lappaconitine, which were verified by a mouse acetic acid-induced writhing test, a mouse hot plate test, and rat paw and mouse ear edema models.

Wang et al., [65] confirmed the in vitro effects of bulleyaconitine A on neuronal voltage-gated $\mathrm{Na}^{+}$channels under the whole cell patch-clamp configuration of rat pituitary $\mathrm{GH}_{3}$ cells expressing Nav1.1, 1.2, 1.3 and 1.6 isoforms. Next, they injected bulleyaconitine A in a volume of $0.2 \mathrm{~mL}$ into the sciatic notch of the left hind limb of rats after inhalational anesthesia with sevoflurane and determined changes in sensory and motor functions. Bulleyaconitine A blocked both sensory and motor function of the sciatic nerves at $0.375 \mathrm{mM}$, although it induced hyperexcitability and cardiac arrhythmia following the sciatic nerve block. Co-injection of $0.375 \mathrm{mM}$ bulleyaconitine A with $2 \%$ lidocaine or epinephrine $(1: 100,000)$ decreased such systemic toxicity and prolonged the nerve-blocking duration to $\sim 4 \mathrm{~h}$. In their following study [66], the effects of bulleyaconitine A on voltage-gated $\mathrm{Na}^{+}$channels were evaluated by recording $\mathrm{Na}^{+}$currents of human embryonic kidney cells expressing different $\mathrm{Nav}$ isoforms and by measuring the cutaneous trunci muscle reflex after subcutaneous (via dorsal skin) injection of $0.6 \mathrm{~mL}$ test solution to rats. Bulleyaconitine A blocked Nav1.7 and Nav1.8 $\mathrm{Na}^{+}$currents at $10 \mu \mathrm{M}$ and induced the complete nociceptive blockade lasting for $\sim 3 \mathrm{~h}$ at $0.125 \mathrm{mM}$. When co-injecting $0.125 \mathrm{mM}$ bulleyaconitine A with $0.5 \%$ lidocaine/epinephrine (1:200,000), the duration of cutaneous analgesia was increased from $3 \mathrm{~h}$ to $24 \mathrm{~h}$ without adverse effects.

With respect to local anesthetic Aconitum and Delphinium alkaloids, Turabekova et al., [67] recently published an excellent report on the relationship between structure and activity to antagonize voltage-gated $\mathrm{Na}^{+}$channels.

Tsuchiya [68] examined the membrane effects of $\beta$-carboline alkaloids on lipid bilayer membranes by a fluorescence polarization method. He demonstrated that tetrahydroharman and tetrahydronorharman (Figure 4) interact with biomimetic membranes to show biphasic effects that increase the membrane fluidity at high micromolar concentrations but decrease at low nanomolar concentrations. There is the possibility that these membrane-interacting alkaloids may counteract the mechanistic membrane effects of local anesthetics to affect their anesthetic efficacy at physiologically-relevant $15 \mathrm{nM}$ [69].

\subsection{Flavonoids}

Flavonoids are polyphenolic phytochemicals that ubiquitously occur in edible and medicinal plants. A number of flavonoids are structurally derived from the parent compound with a tricyclic $\left(C_{6}-C_{3}-C_{6}\right)$ skeleton, sharing a benzene ring $A$ condensed with a heterocyclic six-membered ring $C$ that carries a phenyl ring $\mathrm{B}$ at the 2-position for flavonoids (Figure 5). Based on a structural variation of $C$ ring and its substituents, flavonoids are divided into several subclasses of flavone, flavonol (3-hydroxyflavone), flavanone (dihydroflavone), flavanonol (dihydroflavonol), flavanol (catechin), anthocyanidin with the backbone of 1-benzopyrylium instead of 1-benzopyran-4-one, chalcone lacking the $\mathrm{C}$ ring, and isoflavone with the $\mathrm{B}$ ring at the 3-position. 

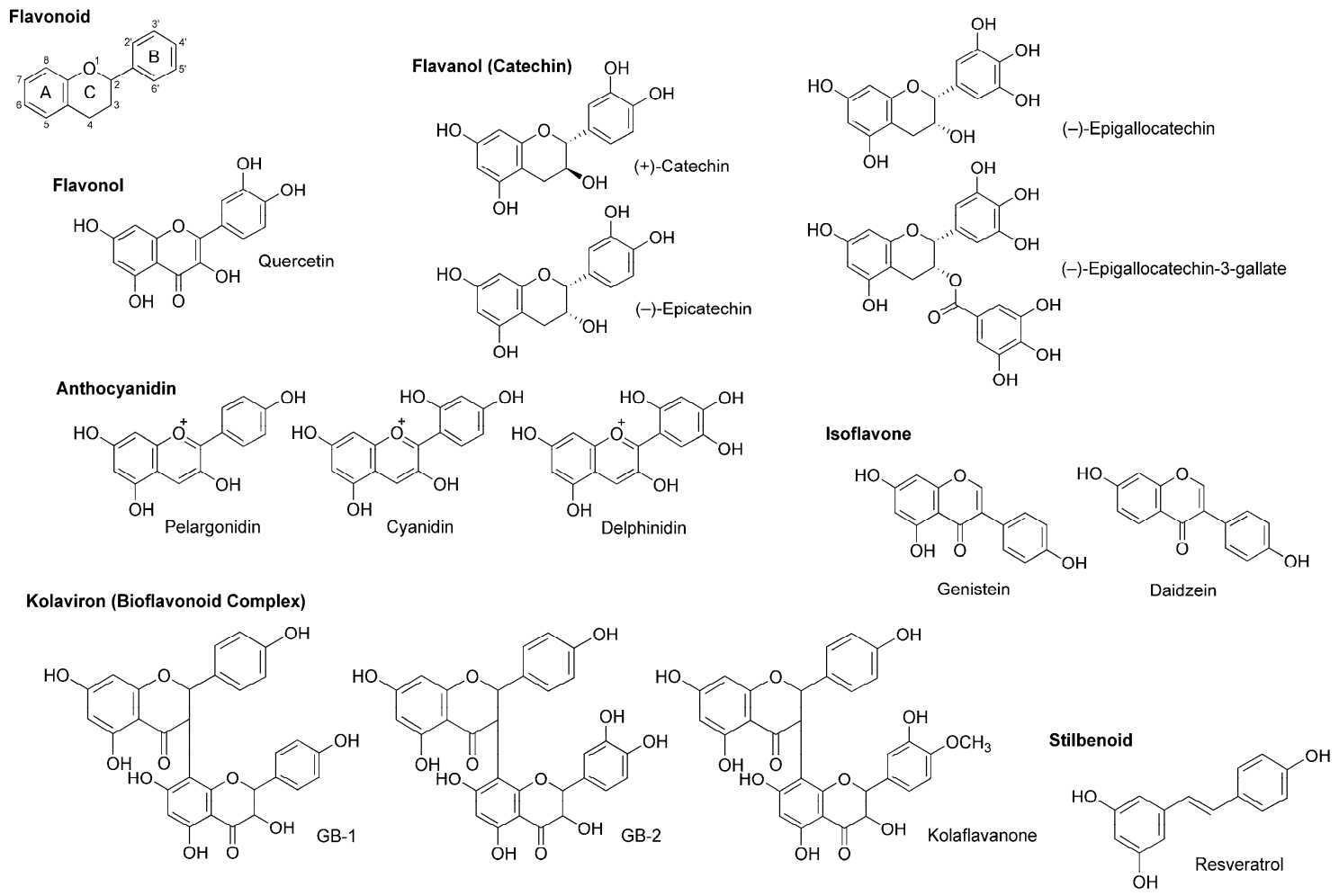

Figure 5. Polyphenolic flavonoids and stilbenoid with local anesthetic activity.

Wu et al., [70] recorded patch-clamp whole-cell currents of mouse dorsal root ganglionic neuronal cells and demonstrated that polyphenols extracted from red wine inhibit voltage-gated $\mathrm{Na}^{+}, \mathrm{K}^{+}$ and $\mathrm{Ca}^{2+}$ channels with $\mathrm{IC}_{50}$ values of $2.5,4.0$ and $0.8-1.5 \mu \mathrm{g} / \mathrm{mL}$, respectively. They referred to active substances as flavonoids like quercetin, $(+)$-catechin, (-)-epicatechin and anthocyanins (mostly 3-glucosides of anthocyanidins) and the stilbenoid resveratrol (Figure 5).

(-)-Epigallocatechin-3-gallate and (-)-epigallocatechin (Figure 5) are best known as the active components in green tea (the product of Camellia sinensis, Theaceae), which possess antiproliferative, antitumor, antimicrobial, antithrombotic, anti-inflammatory, anti-allergic, apoptosis-inducing and antioxidant property. Kim et al., [71] examined their effects on $\mathrm{Na}^{+}$currents in rat dorsal root ganglion neurons. (-)-Epigallocatechin-3-gallate inhibited both TTX-sensitive and TTX-resistant $\mathrm{Na}^{+}$currents more potently than (-)-epigallocatechin.

In in vitro studies of Paillart et al., [72], genistein and daidzein (Figure 5) blocked voltage-sensitive $\mathrm{Na}^{+}$channels in cultured rat brain neurons with $\mathrm{IC}_{50}$ values of 60 and $195 \mu \mathrm{M}$, respectively. Their effects were not mediated by tyrosine kinase inhibition that is well-known as the pharmacological mechanism of isoflavonoids.

Garcinia kola (Guttiferae) is a medicinal plant used for laryngitis, cough and liver disease. Its seeds predominantly contain kolaviron [73], a bioflavonoid complex consisting of 3,8-linked flavanone dimers such as GB-1, GB-2 and kolaflavanone (Figure 5). Tchimene et al., [74] evaluated the local anesthetic activity of ethanol extracts from Garcinia kola seeds and their flavonoid components by an intradermal wheal assay using guinea pigs. GB-1 induced $92 \%$ local anesthesia at $10 \mathrm{mg} / \mathrm{mL}$ (i.d.), being comparable to the effect of lidocaine $(0.66 \mathrm{mg} / \mathrm{kg}$, i.d.).

\subsection{Stilbenoids}

Besides flavonoids, stilbenoids are also part of natural polyphenols contained in plants. The best known polyphenolic stilbene is resveratrol (Figure 5). Resveratrol is referred to as a phytoalexin that plants biosynthesize by pathogen infection and accumulate at the infected area to exhibit the 
antimicrobial activity for protection. Japanese knotweed (Fallopia japonica, Polygonaceae), grapevines and berry fruits such as blueberry, cranberry and bilberry are rich in resveratrol. Since these plants have anti-inflammatory, neuroprotective and cancer preventive property, Kim et al., [75] investigated the effects of resveratrol on TTX-sensitive and TTX-resistant $\mathrm{Na}^{+}$channels implicated in pain pathways. Resveratrol suppressed both types of $\mathrm{Na}^{+}$currents in rat dorsal root ganglion neurons with preference for TTX-sensitive $\mathrm{Na}^{+}$channels.

\section{Phytochemicals with the General Anesthetic Activity}

Although the exact pharmacological mechanisms of general anesthesia are still an open question, currently used general anesthetics and anesthesia-related drugs (sedatives, anxiolytics or anesthetic adjuncts) are considered to target inhibitory $\mathrm{GABA}_{\mathrm{A}}$ receptors and excitatory NMDA receptors [76].

Inhibitory neurotransmitter GABA binds to $\mathrm{GABA}_{\mathrm{A}}$ receptors that are ligand-gated $\mathrm{Cl}^{-}$channels to allow the influx of $\mathrm{Cl}^{-}$into postsynaptic neurons, inhibiting the neuronal excitability through synaptic phase currents and extrasynaptic tonic currents [77]. $\mathrm{GABA}_{\mathrm{A}}$ receptors are expressed in various neurons of cortex, hippocampus, cerebellum and olfactory bulb. While heteromeric $\mathrm{GABA}_{\mathrm{A}}$ receptors are composed of $\alpha$ and $\beta$ subunits, there are distinct subunit combinations in which $\alpha 1 \beta 2 \gamma 2$ (the most abundant receptor isoform) and $\alpha 2 \beta 3 \gamma 2$ are primarily responsible for sedative and anxiolytic effect, respectively, or for both. Intravenous agents such as propofol, etomidate, benzodiazepines and barbiturates, and inhalational agents such as halothane, isoflurane, sevoflurane and nitrous oxide act as a positive allosteric modulator and a direct activator of $\mathrm{GABA}_{\mathrm{A}}$ receptors at clinically relevant concentrations to produce general anesthesia, sedation, anxiolysis and cessation of convulsions. $\mathrm{GABA}_{\mathrm{A}}$ receptors have specific binding sites for GABA and many drugs including benzodiazepines, barbiturates, volatile anesthetics, picrotoxinin, neuro-active steroids and ethanol. The GABAergic system is also mechanistically associated with the effects of volatile odorants contained in essential oils.

NMDA receptors consisting of an NR1 subunit combined with NR2 subunits are activated by glutamate and glycine to open the ion channels nonselective to positively charged cations, resulting in neuronal excitation. Ketamine and nitrous oxide act on NMDA receptors as a non-competitive antagonist and a channel blocker, respectively, to show analgesic, sedative and anesthesia-maintaining effects. Activation of NMDA subtypes of glutamate receptors is also associated with cell damages caused by neuronal ischemia. Therefore, antagonism or inhibition of NMDA receptors is considered to lead to not only dissociative anesthesia but also possible neuroprotection.

In addition to receptor proteins, general anesthetics act on membrane-constituting lipids to modify organization, dynamics and physicochemical properties of biomembranes, resulting in direct disturbance of the function of neuronal membranes and indirect modulation of the receptor activity through a conformational change of membrane-embedded proteins [78]. Propofol preferentially locates in the hydrophobic deeper regions of membrane lipid bilayers to change the fluidity, order, permeability and dynamics of neuronal membranes with the potency correlating to $\mathrm{GABA}_{\mathrm{A}}$ receptor-modulatory effects. Such a membrane interaction mechanism, at least partly but significantly, underlies the effects of intravenous anesthetics, barbiturates, benzodiazepines and ketamine.

Among phytochemicals, terpenoids, flavonoids and alkaloids are expected as the neuro-active lead compounds for general anesthetics and anesthesia-related drugs because they are able to interact with $\mathrm{GABA}_{\mathrm{A}}$ receptors, NMDA receptors and lipid membranes [78,79].

\subsection{Plant Preparations}

Besides exhibiting the local anesthetic and antinociceptive activity, black plum (Vitex doniana, Verbenaceae) has been speculated to have some effect on the central nervous system. In rat in vivo experiments of Abdulrahman et al., [20] and Tijjani et al., [21], aqueous extracts (50-400 mg/ $\mathrm{kg}$, i.p.) from the root bark and ethanol extracts (100-200 mg/ $\mathrm{kg}$, i.p.) from the stem bark potentiated the effects of thiopental (20 mg/kg, i.p.) and pentobarbital (35 mg/kg, i.p.), respectively. 
Zaku et al., [80] reported that aqueous extracts (100-200 mg/kg, i.p.) from the root bark of medicinal plant Ficus sycomorus (Moraceae) increased the effect of aminobarbitone (12 mg/kg, i.p.) on rats. They specified phytochemicals present in the active extracts as terpenoids, alkaloids and flavonoids.

Plants of the genus Passiflora consist of many species, including edible and medicinal plants such as Passiflora incarnata, Passiflora quadrangularis and Passiflora actinia that are used worldwide for anxiety, neuralgia and insomnia. The most popular species, Passiflora incarnata (Passifloraceae), is known as purple passionflower and maypop with the analgesic, anxiolytic, sedative and anticonvulsant activity. Grundmann et al., [81] neuropharmacologically studied the effect of commercially available $50 \%$ ethanol extract from Passiflora incarnata by an elevated plus maze test using mice. The extract (375 mg/kg, p.o.) exerted an anxiolytic effect comparable to that of diazepam (1.5 mg/kg, p.o.).

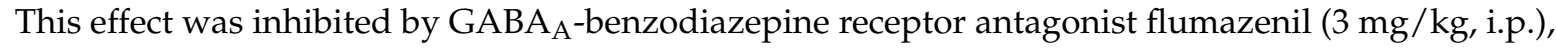
suggesting the mechanistic contribution of the GABAergic system. In in vitro experiments of Appel et al., [82], the same Passiflora incarnata extract inhibited GABA uptake into rat cortical synaptosomes with an $\mathrm{EC}_{50}$ value of $95.7 \mu \mathrm{g} / \mathrm{mL}$ and competed with a specific antagonist for binding to $\mathrm{GABA}_{\mathrm{A}}$ receptors of rat brain membranes with an $\mathrm{IC}_{50}$ value of $101 \mu \mathrm{g} / \mathrm{mL}$. Lolli et al., [83] used another species Passiflora actinia (Passifloraceae) to determine the GABA $\mathrm{A}$ receptor-modulatory activity. Methanol and hydroalcoholic extracts from its leaves showed anxiolytic-like effects at $100-600 \mathrm{mg} / \mathrm{kg}$ (p.o.) in an elevated plus maze test using mice, which were blocked by $\mathrm{GABA}_{\mathrm{A}}$-benzodiazepine receptor antagonist flumazenil (10 mg/kg, i.p.).

\subsection{Essential Oils and Terpenoids}

Etomidate, barbiturates, benzocaine and lidocaine are used to immobilize aquatic animals and reduce their stress and mortality. In recent years, attention has been paid to the anesthetic effects of plant products because they have the relatively low toxicity compared with conventional synthetic drugs. A series of experiments of Heinzmann et al., in which fishes and crustaceans were submitted to aquaria containing essential oils, revealed that silver catfish and white shrimp are anesthetized by essential oils from Lippia alba (Verbenaceae) [84], Aloysia triphylla (Verbenaceae) [85], Hyptis mutabilis (Lamiaceae) [86] and Hesperozygis ringens (Lamiaceae) [87]. The GABAergic system was suggested to underlie their anesthetic effects. However, whether these results are applicable to mammals and humans is unknown.

Aromatherapy is traditionally utilized for managing pain, anxiety, depression and stress because the aromas of essential oils are very likely to influence emotional responses. Agarwood ("Jinkoh" in Japanese) is a resinous portion of Aquilaria trees in the family Thymelaeaceae and spikenard ("Kanshokoh" in Japanese) is dried root and rhizome of Nardostachys chinensis (Valerianaceae). Both plant preparations are used not only for oriental incense and scented sachet but also as an herbal tranquilizer. Takemoto et al., [88] examined the neuro-activity of agarwood oils and spikenard extracts by a spontaneous vapor administration system and found that mice were sedated by inhaling their vapors. Volatile compounds isolated from the active vapors were also effective at lower concentrations. They identified 10 sesquiterpenes contained in the essential oil prepared from spikenard. When comparing these sesquiterpenes, aristolen-1(10)-en-9-ol (Figure 6) most potently inhibited the locomotion of caffeine-treated mice by approximately $60 \%$ at $300 \mu \mathrm{g} / \mathrm{cage}$ [89]. Inhalation of aristolen-1(10)-en-9-ol prolonged pentobarbital (30 mg/kg, i.p.)-induced sleeping time of mice with the potency comparable to that of diazepam $(1 \mathrm{mg} / \mathrm{kg}$, p.o.). This effect was inhibited by $\mathrm{GABA}_{\mathrm{A}}$-benzodiazepine receptor antagonist flumazenil (3 mg/kg, i.p.), suggesting that the GABAergic system is associated with the neuro-activity of aristolen-1(10)-en-9-ol. Okugawa et al., [90] also reported that agarwood sesquiterpene jinkoh-eremol and agarospirol (Figure 6) showed neuroleptic effects on mice. De Sousa et al., [91] recently published a systematic review about the anxiolytic-like effects of essential oils from Lavendula angustifolia (Lamiaceae), Citrus aurantium (Rutaceae), Alpinia zerumbet (Zingiberaceae) and other aromatic plants. 


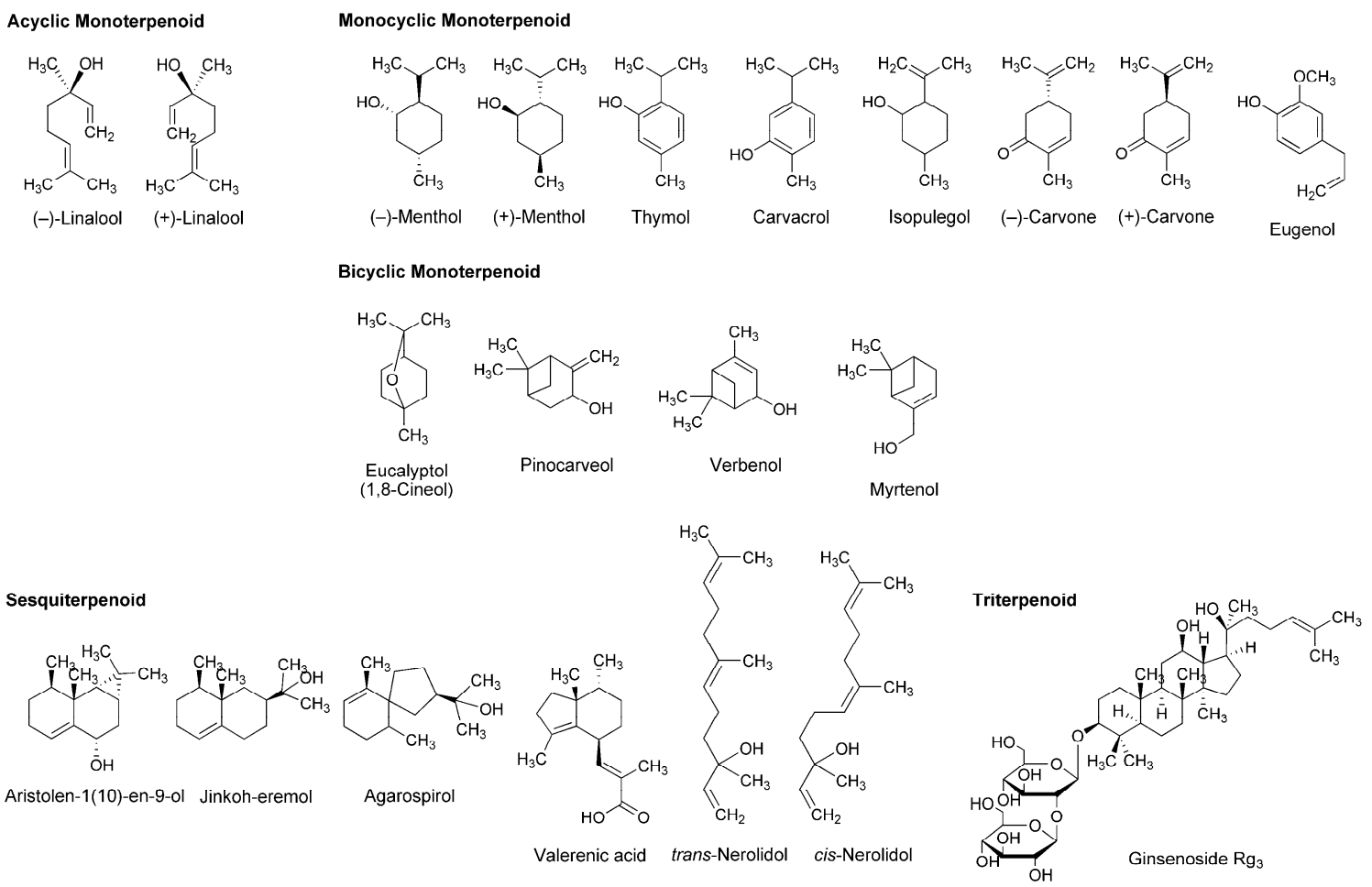

Figure 6. Terpenoids with general anesthetic activity.

Plants of the genus Sideritis (Lamiaceae) are used to make tea with the sedative and antioxidant property. Kessler et al., [92] identified different terpenoids in the extracts from Sideritis arguta, Sideritis condensata, Sideritis stricta and Sideritis sipylea. They investigated the effects of these Sideritis terpenoids on $\mathrm{GABA}_{\mathrm{A}}$ receptor $\alpha 1 \beta 2$ or $\alpha 1 \beta 2 \gamma 2$ subunits expressed in Xenopus laevis oocytes or human embryonic kidney cells. Monocyclic isopulegol and bicyclic pinocarveol, verbenol and myrtenol (Figure 6) significantly modulated $\mathrm{GABA}_{\mathrm{A}}$ receptor functions at 3-300 $\mu \mathrm{M}$ independently of the $\gamma 2$ subunit as well as general anesthetics.

The root extract of valerian, a perennial flowering plant of the genus Valerian, is utilized as a sedative or tranquilizer in herbal medicine. Valeriana officinalis (Valerianaceae) most widely used in Europe and USA contains sesquiterpene valerenic acid (Figure 6). Yuan et al., [93] demonstrated that a commercially available valerian extract and valerenic acid inhibit $\mathrm{GABA}_{\mathrm{A}}$ receptor agonist muscimol-sensitive neurons in neonatal rat brainstem preparations with $\mathrm{IC}_{50}$ values of $240 \mu \mathrm{g} / \mathrm{mL}$ and $23 \mu \mathrm{M}$, respectively. These effects were antagonized by $\mathrm{GABA}_{A}$ receptor antagonist bicuculline at $10 \mu \mathrm{M}$. Khom et al., [94] and Traune et al., [95] reported that valerenic acid allosterically subunit-specifically modulated $\mathrm{GABA}_{\mathrm{A}}$ receptors and enhanced $\mathrm{Cl}^{-}$currents through $\mathrm{GABA}_{\mathrm{A}}$ receptors expressed in Xenopus laevis oocytes. By a radioligand binding assay with crude rat brain membranes, Benke et al., [96] revealed that valerenic acid allosterically interacts with benzodiazepine and GABA binding sites of $\mathrm{GABA}_{\mathrm{A}}$ receptors. In the in vivo experiments, valerenic acid $(1-6 \mathrm{mg} / \mathrm{kg}$, i.p. and $10 \mathrm{mg} / \mathrm{kg}$, p.o.) also showed anxiolytic effects on mice.

In addition to local anesthetic and anti-inflammatory effects [32], acyclic monoterpene (-)-linalool (Figure 6) exhibits the antinociceptive activity associated with the blockade of NMDA receptors and the activation of cholinergic, opioidergic and dopaminergic systems [97], but not with the modulation of $\mathrm{GABA}_{\mathrm{A}}$ receptors [98]. Linck et al., [99] placed mice for $60 \mathrm{~min}$ in a chamber of an atmosphere saturated with $1 \%$ or $3 \%$ racemic linalool. Inhaling linalool increased the time of sleep induced by intraperitoneal pentobarbital administration. Sugawara et al., [100] compared lavender oil (-)-linalool, coriander oil (+)-linalool and racemic linalool, and concluded that $(-)$-linalool is most effective in 
sedating humans. Heldwein et al., [101] indicated that (+)-linalool from Lippia alba (Verbenaceae) is primarily responsible for sedation and anesthesia of silver fish.

Watt et al., [102] examined the effect of monocyclic monoterpene menthol on recombinant human $\mathrm{GABA}_{\mathrm{A}}$ receptors expressed in Xenopus laevis oocytes. Menthol enhanced sub-maximal GABA currents at 3-300 $\mu \mathrm{M}$ and shared the site of action on $\mathrm{GABA}_{\mathrm{A}}$ receptors with propofol. Lau et al., [103] investigated the effect of menthol on $\mathrm{GABA}_{\mathrm{A}}$ receptor-mediated currents of rat midbrain periaqueductal grey neurons by a whole-cell voltage clamp recording experiment. They showed that menthol prolongs at $150-750 \mu \mathrm{M}$ the duration of spontaneous inhibitory postsynaptic potentials mediated by $\mathrm{GABA}_{\mathrm{A}}$ receptors.

Reiner et al., [15] studied the action of terpenoid phenols on primary cultures of mouse cortical neurons. Thymol, carvacrol and eugenol enhanced the binding of $\left[{ }^{3} \mathrm{H}\right]$ flunitrazepam to $\mathrm{GABA}_{\mathrm{A}}$ receptors with micromolar $\mathrm{EC}_{50}$ values and increased $2 \mu \mathrm{M} \mathrm{GABA-evoked} \mathrm{Cl}^{-}$influx at micromolar concentrations. Priestley et al., [104] showed that thymol potentiates $\mathrm{EC}_{20}$ GABA responses at $1-100 \mu \mathrm{M}$ by using human $\mathrm{GABA}_{\mathrm{A}}$ receptor subunit combinations expressed in Xenopus laevis oocytes. García et al., [14] evaluated the positive allosteric modulatory effect of thymol on $\mathrm{GABA}_{\mathrm{A}}$ receptors in primary cultures of mouse cortical neurons. Thymol enhanced $5 \mu \mathrm{M} \mathrm{GABA-induced} \mathrm{Cl}^{-}$influx with an $\mathrm{EC}_{50}$ value of $12 \mu \mathrm{M}$ and directly enhanced the $\mathrm{Cl}^{-}$influx with an $\mathrm{EC}_{50}$ value of $135 \mu \mathrm{M}$. Its direct effect was inhibited by competitive and non-competitive $\mathrm{GABA}_{\mathrm{A}}$ receptor antagonists. While phenol derivatives with aliphatic substituents at the ortho-position commonly have the property to activate $\mathrm{GABA}_{\mathrm{A}}$ receptors directly, propofol (2,6-diisopropylphenol) most potently activated $\mathrm{Cl}^{-}$currents via rat $\mathrm{GABA}_{\mathrm{A}}$ receptors heterologously expressed in human embryonic kidney cells with an $\mathrm{EC}_{50}$ value of $23 \mu \mathrm{M}$, followed by thymol (2-isopropyl-5-methylphenol) with an $\mathrm{EC}_{50}$ value of $200 \mu \mathrm{M}$ [105].

The triterpenoid ginsenosides $\mathrm{Rb}_{1}, \mathrm{Rb}_{2}, \mathrm{Rc}, \mathrm{Re}, \mathrm{Rf}, \mathrm{Rg}_{1}, \mathrm{Rg}_{2}, \mathrm{Rg}_{3}, \mathrm{Rh}_{1}$ and $\mathrm{Rh}_{2}$ are contained in ginseng that is traditionally used for improving mood, vitality and sexual function and for treating depression, anxiety and memory problem. Kim et al., [106] revealed that total ginsenosides in ginseng inhibit $100 \mu \mathrm{M}$ NMDA-produced $\mathrm{Ca}^{2+}$ increase in cultured rat hippocampal neurons with an $\mathrm{IC}_{50}$ value of $26.6 \mu \mathrm{g} / \mathrm{mL}$. When comparing several ginsenosides, ginsenoside $\operatorname{Rg}_{3}$ (Figure 6) was most effective in attenuating the NMDA receptor-mediated $\mathrm{Ca}^{2+}$ influx to show an $\mathrm{IC}_{50}$ value of $3.8 \mu \mathrm{M}$. Such effects may be related to neuroprotection because injuries of the central nervous system trigger an over release of glutamate that causes the excessive activation of glutamate receptors of NMDA subtypes.

Membrane lipids regulate $\mathrm{GABA}_{\mathrm{A}}$ receptors, NMDA receptors and ion channels embedded in biomembranes [107]. The pharmacological effects of anesthetics and anesthesia-related drugs are induced by not only the interactions with receptor and channel proteins to modulate their activity but also the interactions with membrane-constituting lipids to alter lipid environments surrounding these functional proteins. Reiner et al., [17] demonstrated that monoterpene thymol, eugenol and carvacrol act on phospholipid multilamellar vesicles to increase the membrane fluidity at 50-200 $\mu \mathrm{M}$ together with modulating $\mathrm{GABA}_{\mathrm{A}}$ receptors positively as well as intravenous anesthetic propofol. Tsuchiya and Mizogami [108] compared membrane effects of thymol, eugenol and their structurally-related anesthetics including propofol. Propofol most potently interacted with neuro-mimetic membranes at 0.1-10 $\mu \mathrm{M}$, followed by thymol and eugenol. Mendanha et al., [55] reported that sesquiterpene nerolidol interacted with erythrocyte and fibroblast membranes to change their fluidity more significantly than racemic menthol, racemic carvone and eucalyptol (Figure 6). While ginkgo contains diterpenoids and sesquiterpenoids, in vivo experiments of DeFeudis and Drieu [109] showed that oral administration to mice of the extracts from Ginkgo biloba leaves $(100 \mathrm{mg} / \mathrm{kg} /$ day) for three weeks increases the fluidity of neuronal membranes simultaneously with improving the short-term memory in a passive avoidance paradigm. The membrane interactions of terpenoids are associated with depression of the central nervous system and potentiation of general anesthetic effects [15]. 


\subsection{Alkaloids}

Passionflower is the general term for plants of the genus Passiflora, of which Passiflora incarnata (Passifloraceae) is the most popular species, followed by Passiflora edulis (Passifloraceae) and Passiflora foetida (Passifloraceae). Its leaves, roots and tea products are used for insomnia, anxiety, neuralgia, epilepsy, hysteria, ulcers, burns and inflammation. Alkaloid components are presumed to be responsible for these effects through $\mathrm{GABA}_{\mathrm{A}}$ receptor modulation. They are very likely to belong to harmala alkaloids that were originally found in Peganum harmala (Nitrariaceae) and identified as phytochemicals with the common $\beta$-carboline structure like harman, harmine, harmaline, harmol and halmalol (Figure 7). When Aricioglu and Altunbas [110] administered harman (2.5-10 mg/kg, i.p.) to rats, the time of immobility in a forced swim test and the time spent in open arms in an elevated plus maze were decreased and increased, respectively. Farzin and Mansouri [111] also reported that harman (5-15 mg/kg, i.p.), norharman (2.5-10 mg/kg, i.p.) and harmine (5-15 mg/kg, i.p.) decreased the time of immobility of mice. These effects were inhibited by $\mathrm{GABA}_{\mathrm{A}}$-benzodiazepine receptor antagonist flumazenil (5 mg/kg, i.p.).

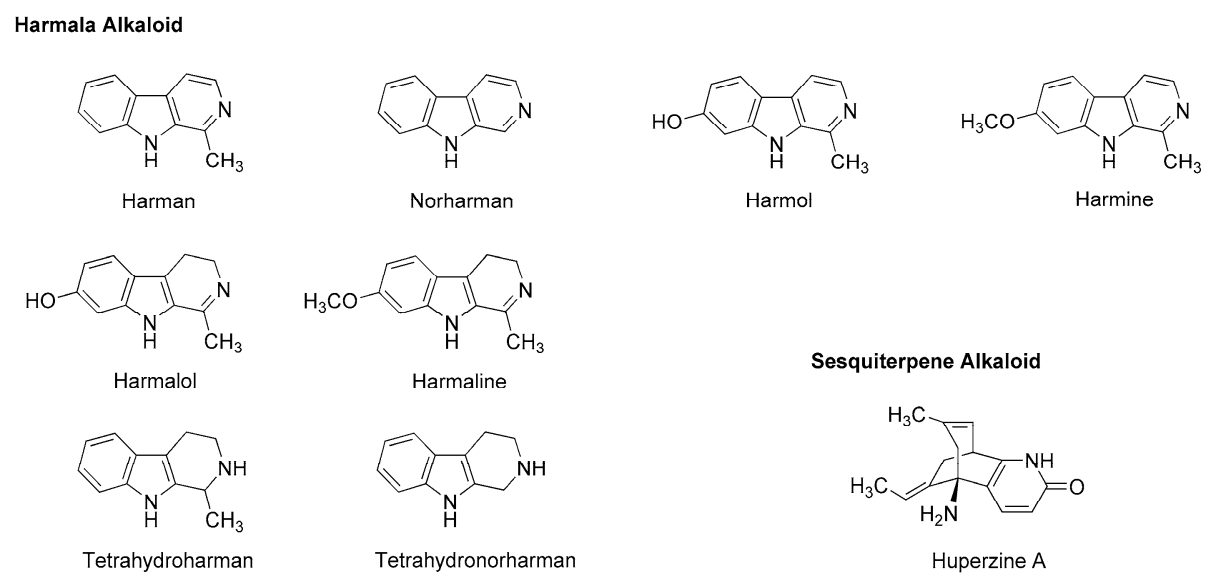

Figure 7. Alkaloids with general anesthetic activity.

Neuro-active harmala alkaloids such as tetrahydroharman and tetrahydronorharman (Figure 7) also have the property to act on membrane lipids. Tsuchiya [68] investigated their effects on biomimetic phospholipid bilayer membranes to verify one of possible pharmacological mechanisms. Tetrahydroharman showed a concentration-dependent biphasic effect to increase the membrane fluidity at $\geq 100 \mu \mathrm{M}$ but decrease the membrane fluidity at $\leq 1.0 \mu \mathrm{M}$. Since tetrahydroharman inhibits the mechanistic membrane effect of propofol at nanomolar concentrations, this alkaloid may potentially affect the anesthetic efficacy of propofol [112].

Chinese herb Huperzia serrata (Huperziaceae) contains sesquiterpene alkaloid huperzine A (Figure 7). By whole-cell voltage clamp recording in CA1 pyramidal neurons dissociated from rat hippocampus, Zhang and $\mathrm{Hu}$ [113] revealed that huperzine A non-competitively inhibits NMDA-induced currents with an $\mathrm{IC}_{50}$ value of $126 \mu \mathrm{M}$ in a voltage- and use-independent manner. This alkaloid may be effective for neurodegenerative diseases as a non-competitive antagonist of NMDA receptors.

\subsection{Flavonoids}

A variety of flavonoids have been suggested to act as an allosteric modulator of $\mathrm{GABA}_{\mathrm{A}}$ receptors [114]. Grundmann et al., [81] reported that the anxiolytic effect of Passiflora incarnata extracts was inhibited by $\mathrm{GABA}_{\mathrm{A}}$-benzodiazepine receptor antagonist flumazenil. They identified the isolated active components as flavone glycoside isoorietin (luteolin-6-C-glucoside), orietin (luteolin-8-C-glucoside), isovitexin (apigenin-6-C-glucoside) and vitexin (apigenin-8-C-glucoside) (Figure 8). 


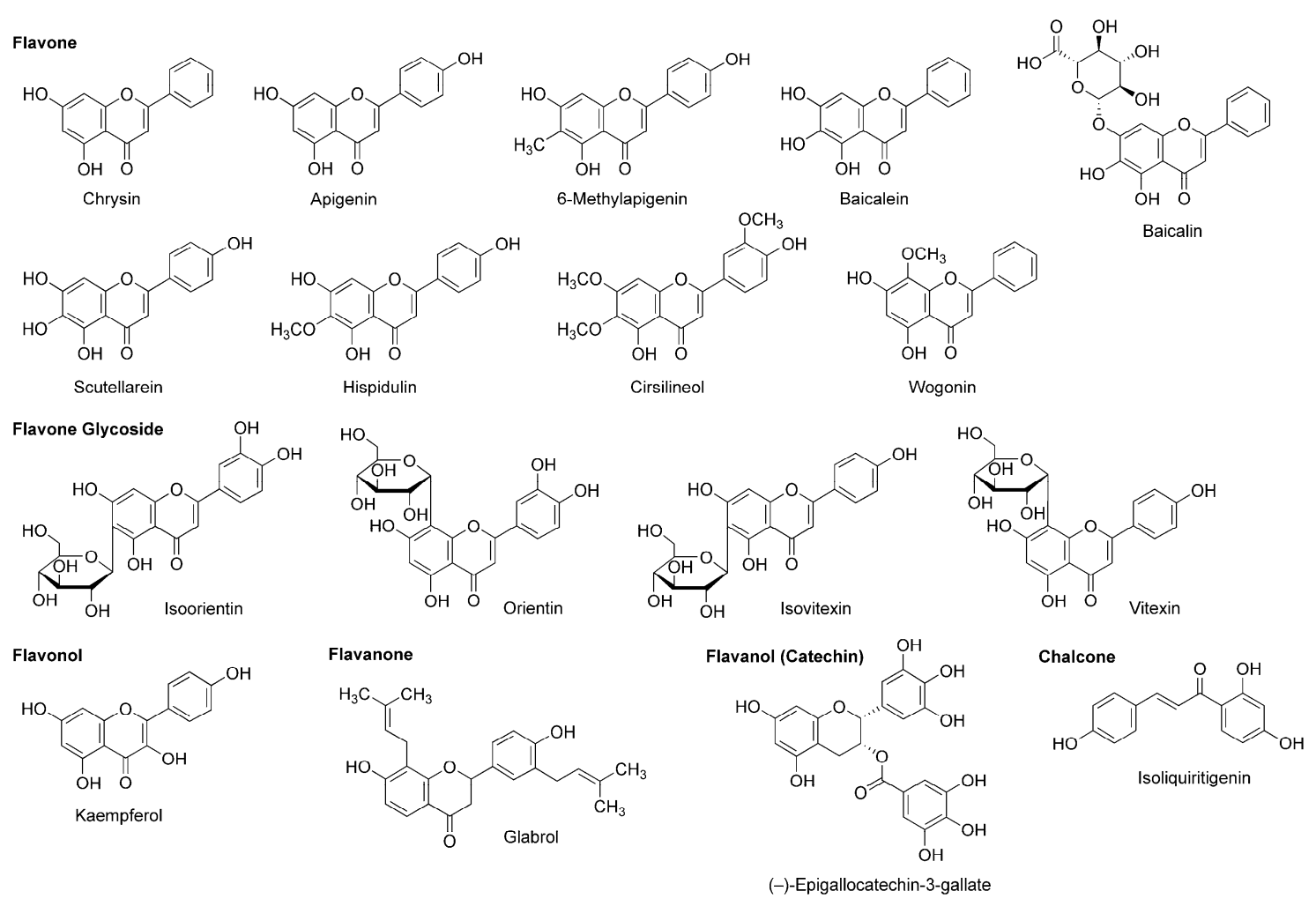

Figure 8. Flavonoids with general anesthetic activity.

While chamomile is the common name for several plant species of the family Asteraceae, tea made from Matricaria recutita (Asteraceae) is used for treating anxiety, stress, insomnia and inflammation. Apigenin (Figure 8) contained in such tea has the property of a benzodiazepine partial agonist. Jäger et al., [115] fractionated the extract from Tanacetum parthenium (Asteraceae) by flumazenil binding assay-guided chromatography and isolated apigenin with the affinity for a $\mathrm{GABA}_{\mathrm{A}}$-benzodiazepine site. Wasowski et al., [116] isolated another sedative flavone 6-methylapigenin (Figure 8) from Valeriana wallichii (Valerianaceae) by flunitrazepam competitive assay-guided chromatography. 6-Methylapigenin showed higher affinity for $\mathrm{GABA}_{\mathrm{A}}$ receptors than apigenin.

(-)-Epigallocatechin-3-gallate (Figure 8) is the most active flavanol contained in green tea, the product of Camellia sinensis (Theaceae). Park et al., [117] suggested that its anxiolytic and sedative effects are mediated by $\mathrm{GABA}_{\mathrm{A}}$ receptors. In their in vitro and in vivo experiments, (-)-epigallocatechin-3-gallate (5-20 mg/kg, p.o.) prolonged the sleeping time of mice induced by pentobarbital (42 $\mathrm{mg} / \mathrm{kg}$, i.p.) together with increasing the $\mathrm{Cl}^{-}$influx in primary cultured cerebellar cells. Campbell et al., [118] compared the effects of flavonoids on recombinant human $\mathrm{GABA}_{\mathrm{A}}$ receptors expressed in Xenopus laevis oocytes and demonstrated that $0.1 \mu \mathrm{M}(-)$-epigallocatechin-3-gallate and $8 \mu \mathrm{M}$ apigenin enhance $5 \mu \mathrm{M}$ GABA-induced receptor activation and $3 \mu \mathrm{M}$ diazepam-induced positive receptor modulation by up to $52 \%$ and $22 \%$, respectively.

Salah and Jäger [119] isolated hispidulin and cirsilineol (Figure 8) from a perennial shrub Artemisia herba-alba (Asteraceae). In their in vitro study, these flavones acted on $\mathrm{GABA}_{\mathrm{A}}$-benzodiazepine receptors with $\mathrm{IC}_{50}$ values of $8 \mu \mathrm{M}$ for hispidulin and $100 \mu \mathrm{M}$ for cirsilineol.

In addition to neuro-active $\beta$-carboline alkaloids, plants of the genus Passiflora contain sedative flavonoids such as apigenin, chrysin and kaempferol (Figure 8). Because aqueous extracts (100-300 mg/kg, p.o.) from the pericarp of Passiflora quadrangularis (Passifloraceae) prolonged the sleep duration of mice in an ethyl ether-induced hypnosis test, Gazola et al., [120] evaluated the neurological effects of their main component apigenin. Apigenin $(0.6 \mathrm{mg} / \mathrm{kg}$, p.o.) sedated mice and this effect was 
blocked by flumazenil (1 mg/kg, i.p.), suggesting that apigenin modulates the benzodiazepine site of $\mathrm{GABA}_{\mathrm{A}}$ receptors. Brown et al., [121] neuropharmacologically studied another flavone component chrysin. They administered chrysin ( $2 \mathrm{mg} / \mathrm{kg}$, i.p.) or midazolam $(1.5 \mathrm{mg} / \mathrm{kg}$, i.p.) to rats $30 \mathrm{~min}$ before behavioral evaluations by an elevated plus maze test. Chrysin exerted an anxiolytic effect, which was affected by co-administered $\mathrm{GABA}_{\mathrm{A}}$-benzodiazepine receptor antagonist flumazenil (3 mg/kg, i.p.).

Skullcap (Scutellaria lateriflora, Lamiaceae) is used as an herbal medicine for anxiety, sedation, insomnia and neuralgia. Awad et al., [122] measured the relative anxiety level of rats by an elevated plus maze test and confirmed the anxiolytic activity of an aqueous skullcap extract $(1.0 \mathrm{~mL} \mathrm{of} 100 \mathrm{mg}$ extract/mL, p.o.). They identified two relevant flavone components as baicalein and baicalin (Figure 8). Based on the in vitro experimental result of baicalein that acted on the benzodiazepine binding site of $\mathrm{GABA}_{\mathrm{A}}$ receptors, Liao et al., [123] verified in vivo effects of baicalein and its 7-glucuronide. Baicalein (10 mg/kg, i.p.) and baicalin (20 mg/ kg, i.p.) induced anxiolysis in mice, which was antagonized by $\mathrm{GABA}_{\mathrm{A}}$-benzodiazepine receptor antagonist flumazenil (2 mg/kg, i.p.).

Tea made from flavonoid-rich leaves of Apocynum venetum (Apocynaceae) is used in traditional Chinese medicine. Grundmann et al., [124] assessed the neurological activity of 70\% ethanol extracts from the leaves of Apocynum venetum by an elevated plus maze test using mice. They demonstrated that the extracts are anxiolytic at two distinct concentrations of $22.5-30 \mathrm{mg} / \mathrm{kg}$ (p.o.) and 100-125 mg/kg (p.o.). They isolated flavonol kaempferol (Figure 8) from the active extracts. In their in vivo experiments, kaempferol $(0.02-1.0 \mathrm{mg} / \mathrm{kg}$, p.o.) showed an anxiolytic effect on mice with the potency comparable to that of diazepam $(1.5 \mathrm{mg} / \mathrm{kg}$, p.o.) and the effect of kaempferol $(0.08 \mathrm{mg} / \mathrm{kg}$, p.o.) was antagonized by $\mathrm{GABA}_{\mathrm{A}}$-benzodiazepine receptor antagonist flumazenil (3 mg/kg, i.p.).

Scutellaria baicalensis (Lamiaceae) is a Chinese medicinal herb with the sedative and antibacterial property. Hui et al., [125] isolated flavone wogonin (Figure 8) from this plant. Their radioreceptor binding assay showed that wogonin has the affinity for the benzodiazepine site of $\mathrm{GABA}_{\mathrm{A}}$ receptors in rat forebrain synaptosomal membranes with a $K i$ value of $0.92 \mu \mathrm{M}$. In the electrophysiological experiments, wogonin enhanced GABA-activated currents of rat dorsal root ganglion neurons and recombinant rat $\mathrm{GABA}_{\mathrm{A}}$ receptors expressed in Xenopus laevis oocytes. Wogonin $(7.5-30 \mathrm{mg} / \mathrm{kg}$, p.o.) also showed in vivo anxiolytic effects on mice. Baicalein, baicalin and scutellarein (Figure 8 ) isolated from the root of Scutellaria baicalensis (Lamiaceae) bind to the benzodiazepine site of $\mathrm{GABA}_{\mathrm{A}}$ receptors with lower affinity than that of wogonin [126].

The chalcone isoliquiritigenin (Figure 8) is contained in licorice, the root of Glycyrrhiza glabra (Fabaceae) that is used as a flavoring agent. Isoliquiritigenin was found to exert an anxiolytic effect on mice in an elevated plus maze test [127]. Cho et al., [128] demonstrated that isoliquiritigenin (25-50 mg/kg, p.o.) potentiates pentobarbital (45 mg/kg, i.p.)-induced sleep in mice, which was fully inhibited by $\mathrm{GABA}_{\mathrm{A}}$-benzodiazepine receptor antagonist flumazenil $(8 \mathrm{mg} / \mathrm{kg}$, i.p.). Their radioreceptor binding assay and electrical measurement showed that isoliquiritigenin has the binding affinity for $\mathrm{GABA}_{\mathrm{A}}$-benzodiazepine receptors in rat cerebral cortex membranes with a $K i$ value of $0.45 \mu \mathrm{M}$ and it increases $2 \mu \mathrm{M}$ GABA-evoked currents in rat dorsal raphe neurons by $151 \%$ at $10 \mu \mathrm{M}$. These results indicate that isoliquiritigenin is a positive allosteric modulator of $\mathrm{GABA}_{\mathrm{A}}$-benzodiazepine receptors. Woo et al., [129] investigated the modulatory effect of isoliquiritigenin on GABAergic synaptic responses in mouse hippocampal CA1 pyramidal neurons by using a whole-cell patch clamp technique. Isoliquiritigenin prolonged at $1 \mu \mathrm{M}$ the decay of spontaneous inhibitory postsynaptic currents mediated by $\mathrm{GABA}_{\mathrm{A}}$ receptors. Its effect was inhibited by benzodiazepine antagonist flumazenil at $5 \mu \mathrm{M}$. Isoliquiritigenin also competitively binds to the glutamate recognition site of NMDA receptors in rat cerebral cortex membranes. Kawakami et al., [130] reported that isoliquiritigenin inhibited $300 \mu \mathrm{M}$ NMDA-induced increase of the $\mathrm{Ca}^{2+}$ influx in cultured rat cortical neurons at 100-300 $\mu \mathrm{M}$. Such an NMDA receptor antagonistic effect may contribute to protection against glutamate excitatory neurotoxicity rather than to production of anesthesia.

Cho et al., [131] revealed that ethanol extracts (250-500 $\mathrm{mg} / \mathrm{kg}$, p.o.) from licorice potentiate pentobarbital (45 mg/kg, i.p.)-induced sleep in mice, which was inhibited by benzodiazepine 
antagonist flumazenil ( $8 \mathrm{mg} / \mathrm{kg}$, i.p.). Flavanone glabrol (Figure 8 ) isolated from the active extracts inhibited the binding of flumazenil to $\mathrm{GABA}_{\mathrm{A}}$-benzodiazepine receptors in rat cerebral cortex membranes with the affinity of a Ki value of $1.63 \mu \mathrm{M}$. In in vivo experiments, glabrol ( $25-50 \mathrm{mg} / \mathrm{kg}$, p.o.) increased the sleep duration and decreased the sleep latency of mice treated with pentobarbital ( $45 \mathrm{mg} / \mathrm{kg}$, i.p.). These effects were blocked by flumazenil, suggesting that glabrol is a positive allosteric modulator of $\mathrm{GABA}_{\mathrm{A}}$-benzodiazepine receptors.

The interactions of flavonoids with $\mathrm{GABA}_{\mathrm{A}}$ receptors via multiple binding sites and their effects in the central nervous system were recently reviewed by Hanrahan et al., [132] and by Jäger and Saaby [133].

In addition to receptor and channel proteins, flavonoids mechanistically act on membrane lipids. Various flavonoids were reported to interact with phospholipid bilayers and biological membranes to modify their physicochemical properties [134-136]. Their membrane interactivity is also associated with antioxidant, antitumor and antibacterial effects [137].

\section{Clinical Applicability of Phytochemicals}

Previous in vitro and in vivo experiments indicate that phytochemical terpenoids, alkaloids and flavonoids exhibit the local and general anesthetic activity through the molecular mechanisms common to currently used anesthetics and anesthesia-related drugs. Different classes of phytochemicals to interact with receptors, ion channels and lipid membranes have been subjected to the administration experiments with animals and the pre-clinical trials in human subjects.

\subsection{Local Anesthetic Phytochemicals}

When administered to the conjunctival sac at $\mu \mathrm{g} / \mathrm{mL}$ concentrations, linalool, linalyl acetate, menthol, $\alpha$-terpineol, anethole, furanodiene-6-one, methoxyfuranoguaia-9-ene-8-one and (-)- $\beta$-caryophyllene induce local anesthesia in rats and rabbits, which reaches a maximum potency immediately after administration (within $5 \mathrm{~min}$ ) and disappears in a short time (within $15 \mathrm{~min}$ ) [30,33,51,53,54]. Despite promising experimental effects, however, these anesthetic terpenoids have not been applied to humans.

Although it is ideal for local anesthetics to block neuronal $\mathrm{Na}^{+}$channels specifically, conventional local anesthetics are non-specific $\mathrm{Na}^{+}$channel blockers that target not only $\mathrm{Na}^{+}$but also $\mathrm{K}^{+}$and $\mathrm{Ca}^{2+}$ channels. In contrast, neurotoxin alkaloids preferentially block $\mathrm{Na}^{+}$channels by binding to the sites different from those of local anesthetics. Therefore, neurotoxin alkaloids acting on voltage-gated $\mathrm{Na}^{+}$channels are expected to be lead compounds or alternatives for existing anesthetic agents [60]. Wang et al., [66] indicated the ability of bulleyaconitine A to potentiate infiltration anesthesia by in vitro and in vivo studies. Since bulleyaconitine A use-dependently blocked Nav1.7 and Nav1.8 $\mathrm{Na}^{+}$ currents in human embryonic kidney cells expressing neuronal $\mathrm{Na}^{+}$channels, they subcutaneously injected bulleyaconitine $\mathrm{A}(\leq 125 \mu \mathrm{M})$ to rats in combination with $0.5 \%$ lidocaine and epinephrine $(1: 200,000)$. The duration of complete nociceptive blockade was increased from 3 to $24 \mathrm{~h}$ without adverse effects. When injecting test solutions in a volume of $0.2 \mathrm{~mL}$ to rat sciatic notch, $0.375 \mathrm{mM}$ bulleyaconitine A induced sensory and motor blockade that completed 30-60 min after injection and started to recover $1.5-2 \mathrm{~h}$ after injection [65]. By co-injecting with $2 \%$ lidocaine or epinephrine $(1: 100,000)$, bulleyaconitine A prolonged the blocking time of both sensory and motor functions to $4 \mathrm{~h}$ with minimal systemic adverse effects. These results suggest that bulleyaconitine A readily diffuses through the nerve sheath and binds to $\mathrm{Na}^{+}$channels with the relatively slow reversibility compared with conventional local anesthetics. The same local anesthetic property was found in 3 -acetylaconitine, which has been used as an analgesic agent in China. Subcutaneous co-injection of

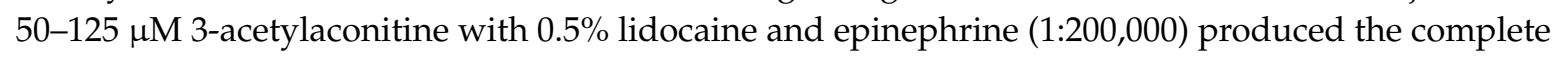
cutaneous analgesia in rats that lasted for $3-12 \mathrm{~h}$ and the full recovery occurred $\sim 5-8$ days after injection [138]. Bulleyaconitine A and 3-acetylaconitine would be useful as an additive to prolong the effects of local anesthetics. Xu et al., [139] investigated the pharmacokinetics of bulleyaconitine A in rats after oral and intravenous administration. Bulleyaconitine $\mathrm{A}$ of $0.04,0.12$ and $0.36 \mathrm{mg} / \mathrm{kg}$ (p.o.) and 
$0.02 \mathrm{mg} / \mathrm{kg}$ (i.v.) showed mean $C_{\max }$ values of 2.11, 5.41, 11.47 and $19.97 \mathrm{ng} / \mathrm{mL}$, respectively, and mean $T_{1 / 2}$ values of $2.48,1.93,2.17$ and $1.23 \mathrm{~h}$, respectively. Weng et al., [140] performed a pharmacokinetic study of bulleyaconitine A in humans. Ten healthy male volunteers were intramuscularly injected with $0.2 \mathrm{mg}$ bulleyaconitine A and blood plasma samples were collected before and $0.17-15 \mathrm{~h}$ after injection. Bulleyaconitine A showed a mean $C_{\max }$ value of $1.13 \mathrm{ng} / \mathrm{mL}$ and a mean $T_{\max }$ value of $0.9 \mathrm{~h}$. However, eight of ten subjects claimed a distinct feeling of pain at the injection site, which started approximately at the time of the peak plasma concentrations and lasted 2-6 h.

Based on the finding that lappaconitine has the ability to block voltage-gated $\mathrm{Na}^{+}$channels, Chen et al., [141] verified the effect of lappaconitine on humans by dividing 50 patients to be operated in the upper abdomen into five groups who received epidural injections of $0,4,8$ and $12 \mathrm{mg}$ lappaconitine or $2 \mathrm{mg}$ morphine as a reference. Consequently, lappaconitine produced analgesia of the satisfactory potency and duration time but no side-effects like morphine, suggesting that the epidural injection of lappaconitine may be useful for postoperative analgesia. In their following study [142], 120 patients were divided into four groups who received epidural injections of test solutions consisting of $12 \mathrm{mg}$ lappaconitine, $12 \mathrm{mg}$ lappaconitine plus $22.5 \mathrm{mg}$ bupivacaine, $22.5 \mathrm{mg}$ bupivacaine or $2 \mathrm{mg}$ morphine during the postoperative pain of incision operation. Epidural co-injection of lappaconitine with bupivacaine showed an analgesic effect with greater potency, earlier initiation and longer maintenance compared with lappaconitine alone and bupivacaine alone, indicating a benefit of lappaconitine co-administered with conventional local anesthetics.

Among $\mathrm{Na}^{+}$channel-blocking Aconitum alkaloids, bulleyaconitine A in solution (i.m.), tablet (p.o.) and soft gel capsule (p.o.) have been prescribed for the treatment of chronic pain and rheumatoid arthritis in China since 1980s [66,140]. Lappaconitine preparations have been also manufactured in China. Long-lasting analgesia induced by bulleyaconitine A may be beneficial for postoperative pain control. Animal administration experiments, pre-clinical trials and pharmacokinetic studies have shown encouraging results. However, most aconitine-like alkaloids with the local anesthetic activity are known to have the drawback of a narrow therapeutic index and the possibility to cause hyperexcitability and cardiac arrhythmia [143].

\subsection{General Anesthetic Phytochemicals}

Plants of the genera Passiflora, Valeriana, Matricaria, Scutellaria, Sideritis, Thymus, Scutellaria and Glycyrrhiz have the property to modulate $\mathrm{GABA}_{\mathrm{A}}$ receptor functions. Among them, several plant species of the genus Passiflora contain neuro-active alkaloids like harman and neuro-active flavonoids like apigenin, both of which have high affinity for $\mathrm{GABA}_{\mathrm{A}}$ receptors. Passiflora incarnata extracts act on the benzodiazepine and ethanol binding sites of $\mathrm{GABA}_{\mathrm{A}}$ receptors [82]. GABAergic phytochemicals in these plants are also expected to interact synergistically with benzodiazepines and barbiturates to potentiate their anesthetic, sedative and anxiolytic effects.

Movafegh et al., [144] verified the utility of Passiflora incarnata as a premedication by a double-blind and placebo-controlled study. Sixty outpatients undergoing inguinal herniorrhaphy were randomized into two groups who orally received either Passiflora incarnata extracts of $500 \mathrm{mg}$ or placebo $90 \mathrm{~min}$ before surgery. When evaluating by a numeric rating scale before and 10-90 min after administration, the extracts reduced anxiety of patients without inducing sedation. Aslanargun et al., [145] performed a randomized, double-blind and placebo-controlled study to determine whether Passiflora incarnata is beneficial for patients undergoing anesthesia and surgery. Each 30 patients received orally commercially available aqueous extracts of Passiflora incarnata of $700 \mathrm{mg} / 5 \mathrm{~mL}$ or the same $5 \mathrm{~mL}$-volume of placebo $30 \mathrm{~min}$ before spinal anesthesia, together with $3 \mathrm{~mL}$ of $0.5 \%$ bupivacaine. Their pre-clinical trial indicated the possibility of Passiflora incarnata premedication to suppress the increase of anxiety levels in the preoperative period without changing psychomotor functions.

Benzodiazepines are most widely prescribed for generalized anxiety disorder associated with the GABAergic system. Because of their adverse effects, however, much attention has been paid to an alternative agent. Akhondzadeh et al., [146] pre-clinically compared the efficacy of Passiflora 
extracts with benzodiazepine anxiolytics by a pilot double-blind randomized controlled trial. Eighteen outpatients orally received commercially available extracts of Passiflora incarnata 45 drops/day plus placebo tablet and other 18 outpatients orally received oxazepam $30 \mathrm{mg}$ tablet/day plus placebo drops for four weeks. The extracts were proved to manage generalized anxiety disorder with the potency being almost comparable to that of oxazepam. The plant Passiflora incarnata has been listed as a safe herbal sedative by the US Food and Drug Administration [147]. Its extracts have been manufactured as drop (500 mg, Passipay ${ }^{\mathrm{TM}}$, Iran Darouk) [144] and syrup (700 mg/5 mL, Sandoz, Turkey) [145].

Chamomile, an herbal remedy for relaxation and calming, has been included in the pharmacopoeia of nearly 30 countries [148]. German chamomile Matricaria recutita (Asteraceae) is referred to as the most potent herb. Since in vitro and in vivo animal experiments indicated that chamomile and its flavone component apigenin exert neuro-modulatory effects by acting on the benzodiazepine site of $\mathrm{GABA}_{\mathrm{A}}$ receptors, Amsterdam et al., [149] conducted a randomized, double-blind, placebo-controlled trial of the chamomile therapy for humans with generalized anxiety disorder. Fifty-seven outpatients were randomized into two groups to receive orally either double-blind chamomile extracts or placebos for eight weeks. Chamomile samples were prepared as $220 \mathrm{mg}$ capsules containing the pharmaceutical grade German chamomile extract standardized to a content of $1.2 \%$ apigenin. Anxiety rating scores showed clinically meaningful difference between two groups, suggesting an anxiolytic effect of chamomile that is associated with $\mathrm{GABA}_{\mathrm{A}}$ receptor-acting apigenin.

Skullcap Scutellaria lateriflora (Lamiaceae) is a medicinal herb that has been traditionally used for anxiety, sedation and neuralgia. Wolfson and Hoffmann [150] performed a double-blind and placebo-controlled study, in which 19 healthy volunteers orally received one 350-mg capsule of freeze-dried skullcap, one 100-mg capsule of skullcap extract or two 100-mg capsules of skullcap extract. They found the significant anxiolytic activity of all skullcap preparations. Skullcap contains wogonin, baicalein, baicalin and scutellarein [151]. These flavones are considered to exert neuropharmacological effects by binding to the benzodiazepine site of $\mathrm{GABA}_{\mathrm{A}}$ receptors.

\subsection{Methodological Considerations in Discovering Phytochemical Lead Compounds}

If the anesthetic activity is found in plant samples by screening or preliminary experiments, they are subjected to specification of the relevant phytochemical components. Fractionation and isolation of active substances are commonly guided by the assays of bioactivity and affinity to pharmacological targets. Local anesthetic terpenoids were purified from Commiphora molmol (Burseraceae) by bioassay-guided chromatography [53]. Anxiolytic flavonol was isolated from Apocynum venetum (Apocynaceae) by chromatographic fractionation combined with an elevated plus maze test [124]. The mode of action on anesthetic-targeting channels and receptors is usable as an isolation index. Anesthetic flavonoids were isolated from Tanacetum parthenium (Asteraceae) [115], Valeriana wallichii (Valerianaceae) [116] and Artemisia herba-alba (Asteraceae) [119] by preparative chromatography that was guided by the benzodiazepine radioligand binding assay with $\mathrm{GABA}_{\mathrm{A}}$ receptors. Phytochemicals mechanistically interact with neuronal membranes as well as anesthetics and anesthesia-related drugs [11,152-154]. In addition to bioassay and radioligand binding assay, the membrane interactivity would give another clue to discover anesthetic phytochemicals.

Even if in vivo applications and pre-clinical trials of plant preparations offered the positive evidence for anesthetic effects on experimental animals and human subjects, caution should be taken to interpret such results. The researches to find drug candidates in plants have generally focused on a single bioactive entity. However, attempts to purify and isolate the relevant phytochemicals may be self-defeating because the overall pharmacological activity of plants can rely on the synergistic interaction between different components [155]. A whole extract or a partially purified extract from plants could have advantages over a single isolated phytochemical as suggested by the phenomenon that a combination of some plants are more effective than either plant alone. 


\section{Conclusions}

Results of the literature search suggest that plant preparations and their containing phytochemicals have the potential to become local anesthetic, general anesthetic, antinociceptive, analgesic or sedative drugs. However, well-controlled clinical trials with phytochemical drug candidates and their practical applications to humans are still limited. Nevertheless, there is a possibility that selected phytochemicals could lead to anesthetics and anesthesia-related drugs. Terpenoids, alkaloids and flavonoids are expected to become novel anesthetic agents of plant origin because they meet the mechanistic requirements to interact with receptors, channels and membranes and they have the characteristic molecular structures different from conventional drugs.

Phytochemicals with the anesthetic activity are summarized in Table 1. Among them, voltage-gated $\mathrm{Na}^{+}$channel-blocking alkaloids (such as lappaconitine, bulleyaconitine A, 3-acetylaconitine, etc.) and terpenoids (such as menthol, thymol, carvacrol, linalool, etc.) may be the alternatives for local anesthetics. Their satisfactory results have been obtained from in vitro and in vivo experiments with animals and pre-clinical trials in human subjects. $\mathrm{GABA}_{\mathrm{A}}$ receptor-modulatory flavonoids (such as apigenin, kaempferol, baicalein, wogonin, chrysin, isoliquiritigenin, etc.) may be the lead compounds for general anesthetics and sedatives. Some of them have been successfully applied to experimental animals and humans. Clinical efficacy, adverse action, pharmacokinetics and pharmacodynamics of these phytochemicals remain to be elucidated together with structural modification to enhance the activity or reduce the toxicity. 
Table 1. Phytochemicals with anesthetic activity.

\begin{tabular}{|c|c|c|c|c|}
\hline Phytochemicals & Activities & Experiments & Results & References \\
\hline \multicolumn{5}{|l|}{ Terpenoids } \\
\hline Linalool & LA & In vitro: Monitoring of compound action potentials in frog sciatic nerves & $\begin{array}{l}\text { Exerted local anesthetic effects at } 7.5-30 \mathrm{mM} \text { as well as } 3.5-30 \mathrm{mM} \\
\text { lidocaine }\end{array}$ & [29] \\
\hline $\begin{array}{l}\text { Linalool } \\
\text { Linalyl acetate }\end{array}$ & LA & In vivo: Administration in rabbit conjunctival sac & Depressed conjunctival reflexes by $0.03-2.5 \mathrm{mg} / \mathrm{mL}$ administration & [30] \\
\hline Linalool & LA & $\begin{array}{l}\text { In vitro: Patch-clamp recording of rat sciatic nerves and rat dorsal root } \\
\text { ganglion neurons }\end{array}$ & $\begin{array}{l}\text { Reversely blocked nerve excitability and inhibited voltage-gated } \mathrm{Na}^{+} \\
\text {currents at sub-micromolar concentrations }\end{array}$ & [31] \\
\hline $\begin{array}{l}\text { (-)-Menthol } \\
\text { (+)-Menthol }\end{array}$ & LA & $\begin{array}{l}\text { In vitro and in vivo: Evaluation of the activity using rat phrenic nerve } \\
\text { hemidiaphragm and by rabbit conjunctival reflex test }\end{array}$ & $\begin{array}{l}\text { Reduced the electrically evoked contractions at } 0.1-100 \mathrm{ng} / \mathrm{mL} \text { and } \\
\text { increased the number of stimuli to provoke the conjunctival reflex } \\
\text { at } 30-300 \mu \mathrm{g} / \mathrm{mL}\end{array}$ & [33] \\
\hline Menthol & LA & In vitro: Patch-clamp recording of rat dorsal root ganglion neurons & $\begin{array}{l}\text { Inhibited tetrodotoxin-resistant Nav1.8 and Nav1.9 and } \\
\text { tetrodotoxin-sensitive } \mathrm{Na}^{+} \text {channels depending on micromolar } \\
\text { concentration, voltage and frequency }\end{array}$ & [34] \\
\hline $\begin{array}{l}\text { Carvacrol } \\
\text { Thymol } \\
\text { Citronellol } \\
\text { Bornyl acetate } \\
\text { Citral }\end{array}$ & LA & In vitro: Recording of compound action potentials in frog sciatic nerves & $\begin{array}{l}\text { Reduced compound action potential peak amplitudes } \\
\left(\mathrm{IC} \mathrm{C}_{50}=0.34-7.2 \mathrm{mM} \text { ) and inhibited nerve conduction by blocking }\right. \\
\text { tetrodotoxin-sensitive voltage-gated } \mathrm{Na}^{+} \text {channels }\end{array}$ & [36-38] \\
\hline Carvacrol & LA & $\begin{array}{l}\text { In vitro: Monitoring of rat sciatic nerve compound action potentials and } \\
\text { patch-clamp recording of rat dorsal root ganglion neurons }\end{array}$ & $\begin{array}{l}\text { Reversely blocked the excitability of sciatic nerves }\left(\mathrm{IC}_{50}=0.5 \mathrm{mM}\right) \text { and } \\
\text { reduced voltage-gated Na}{ }^{+} \text {currents }\left(\mathrm{IC}_{50}=0.37 \mathrm{mM}\right)\end{array}$ & [42] \\
\hline Carvacrol & $\begin{array}{l}\text { AA } \\
\text { LA }\end{array}$ & $\begin{array}{l}\text { In vivo: } 50-100 \mathrm{mg} / \mathrm{kg} \text { (p.o.) administration to mice, followed by acetic } \\
\text { acid-induced abdominal constriction, formalin injection and hot plate tests }\end{array}$ & Inhibited nociception induced by different methods & [43] \\
\hline (-)-Carvone & $\begin{array}{l}\text { AA } \\
\text { LA }\end{array}$ & In vivo: $100-200 \mathrm{mg} / \mathrm{kg}$ (i.p.) administration to mice & $\begin{array}{l}\text { Inhibited acetic acid-induced writhing and formalin-induced hind paw } \\
\text { nociception }\end{array}$ & [44] \\
\hline Estragole & LA & In vitro: Patch-clamp recording of rat dorsal root ganglion neurons & $\begin{array}{l}\text { Inhibited total } \mathrm{Na}^{+} \text {currents }\left(\mathrm{IC}_{50}=3.2 \mathrm{mM}\right) \text { and tetrodotoxin-resistant } \\
\mathrm{Na}^{+} \text {currents }\left(\mathrm{IC}_{50}=3.6 \mathrm{mM}\right)\end{array}$ & [46] \\
\hline Citral & LA & In vitro: Monitoring of compound action potentials in rat sciatic nerves & Inhibited compound action potentials $\left(\mathrm{IC}_{50}=0.23 \mathrm{mM}\right)$ & [48] \\
\hline $\begin{array}{l}\alpha \text {-Terpineol } \\
\text { Anethole }\end{array}$ & LA & $\begin{array}{l}\text { In vitro and in vivo: Evaluation of the activity using rat phrenic } \\
\text { nerve-hemidiaphragm and by rabbit conjunctival reflex test }\end{array}$ & $\begin{array}{l}\text { Reduced the electrically evoked contractions at } 0.01-1 \mu \mathrm{g} / \mathrm{mL} \text { and } \\
\text { increased the number of stimuli to evoke the conjunctival reflex at } \\
10-100 \mu \mathrm{g} / \mathrm{mL}\end{array}$ & {$[51]$} \\
\hline p-Cymene & $\begin{array}{l}\text { AA } \\
\text { LA }\end{array}$ & $\begin{array}{l}\text { In vivo: } 50-200 \mathrm{mg} / \mathrm{kg} \text { (i.p.) administration to mice, followed by acetic } \\
\text { acid-induced writhing and formalin-induced hind paw licking tests }\end{array}$ & Showed significant antinociceptive effects in both tests & [52] \\
\hline$\beta$-Caryophyllene & LA & $\begin{array}{l}\text { In vitro and in vivo: Evaluation of the activity using rat phrenic } \\
\text { nerve-hemidiaphragm and by rabbit conjunctival reflex test }\end{array}$ & $\begin{array}{l}\text { Reduced the electrically evoked contractions at } 0.1 \mathrm{ng} / \mathrm{mL} \text { to } 1.0 \mu \mathrm{g} / \mathrm{mL} \\
\text { and increased the number of stimuli to evoke the conjunctival reflex at } \\
10 \mu \mathrm{g} / \mathrm{mL} \text { to } 1.0 \mathrm{mg} / \mathrm{mL}\end{array}$ & [54] \\
\hline
\end{tabular}


Table 1. Cont.

\begin{tabular}{|c|c|c|c|c|}
\hline Phytochemicals & Activities & Experiments & Results & References \\
\hline \multicolumn{5}{|l|}{ Alkaloids } \\
\hline $\begin{array}{l}\text { Lappaconitine } \\
\text { other neurotoxins }\end{array}$ & LA & $\begin{array}{l}\text { In vivo: Rabbit corneal reflex test to drop test solutions }(0.01-1 \%) \text { into the } \\
\text { conjunctival sac and cat neck trunk anesthesia to inject test solutions ( } 0.1 \\
\mathrm{~mL} \text { of } 0.1-0.5 \% \text {, i.c. and s.c.) }\end{array}$ & $\begin{array}{l}\text { Showed greater potency and longer duration of anesthesia than lidocaine } \\
\text { and procaine }\end{array}$ & [61] \\
\hline $\begin{array}{l}\text { Aconitine } \\
\text { 3-Acetylaconitine }\end{array}$ & AA & $\begin{array}{l}\text { In vivo: Intravenous administration to mice, followed by formaldehyde } \\
\text { injection (s.c.) to induce hyperalgesia }\end{array}$ & $\begin{array}{l}\text { Showed antinociceptive effects in the early phase } \\
\left(\mathrm{ED}_{50}=0.027-0.028 \mathrm{mg} / \mathrm{kg}\right) \text { and the late phase }\left(\mathrm{ED}_{50}=0.077-0.097 \mathrm{mg} / \mathrm{kg}\right)\end{array}$ & [63] \\
\hline Bulleyaconitine A & LA & In vivo: Injection of $0.2 \mathrm{~mL}$ test solution into rat sciatic notch & $\begin{array}{l}\text { Blocked sensory and motor functions of the sciatic nerves at } 0.375 \mathrm{mM} \\
\text { Co-injection with } 2 \% \text { lidocaine or epinephrine }(1: 100,000) \text { prolonged the } \\
\text { nerve-blocking duration }\end{array}$ & {$[65]$} \\
\hline Bulleyaconitine A & $\begin{array}{l}\text { LA } \\
\text { AA }\end{array}$ & $\begin{array}{l}\text { In vitro and in vivo: Recording of } \mathrm{Na}^{+} \text {currents of human embryonic } \\
\text { kidney cells expressing Nav isoforms and measurement of the cutaneous } \\
\text { trunci muscle reflex after injection (s.c.) of } 0.6 \mathrm{~mL} \text { test solution }\end{array}$ & $\begin{array}{l}\text { Blocked Nav1.7 and Nav1.8 } \mathrm{Na}^{+} \text {currents at } 10 \mu \mathrm{M} \text { and induced the } \\
\text { complete nociceptive blockade lasting for } \sim 3 \mathrm{~h} \text { at } 0.125 \mathrm{mM} \\
\text { Co-injection with } 0.5 \% \text { lidocaine/epinephrine }(1: 200,000) \text { increased the } \\
\text { duration of analgesia }\end{array}$ & [66] \\
\hline 3-Acetylaconitine & $\begin{array}{l}\text { AA } \\
\text { LA }\end{array}$ & $\begin{array}{l}\text { In vivo: } 50-125 \mu \mathrm{M} \text { (s.c.) co-injection with } 0.5 \% \text { lidocaine and epinephrine } \\
(1: 200,000) \text { to rats }\end{array}$ & Produced the complete analgesia lasting for 3-12 $\mathrm{h}$ & [138] \\
\hline Lappaconitine & $\begin{array}{l}\text { AA } \\
\text { LA }\end{array}$ & Pre-clinical: Patients received epidural injections of 0-12 $\mathrm{mg}$ lappaconitine & $\begin{array}{l}\text { Produced satisfactory analgesia depending on dosages } \\
\text { Suggested the clinical utility for postoperative analgesia }\end{array}$ & [141] \\
\hline Lappaconitine & $\begin{array}{l}\text { AA } \\
\text { LA }\end{array}$ & $\begin{array}{l}\text { Pre-clinical: Patients received epidural injections of test solutions } \\
\text { consisting of } 12 \mathrm{mg} \text { lappaconitine, } 12 \mathrm{mg} \text { lappaconitine plus } 22.5 \mathrm{mg} \\
\text { bupivacaine or } 22.5 \mathrm{mg} \text { bupivacaine }\end{array}$ & $\begin{array}{l}\text { Epidural co-injection of lappaconitine with bupivacaine induced } \\
\text { analgesia with greater potency, earlier initiation and longer maintenance } \\
\text { than lappaconitine alone and bupivacaine alone }\end{array}$ & [142] \\
\hline \multicolumn{5}{|l|}{ Flavonoids } \\
\hline $\begin{array}{l}\text { (-)-Epigallo-catechin- } \\
\text { 3-gallate }\end{array}$ & LA & In vitro: Measurement of $\mathrm{Na}^{+}$currents in rat dorsal root ganglion neurons & Inhibited tetrodotoxin-sensitive and tetrodotoxin-resistant $\mathrm{Na}^{+}$currents & [71] \\
\hline Genistein Daidzein & LA & In vitro: Measurement of $\mathrm{Na}^{+}$currents in cultured rat brain neurons & $\begin{array}{l}\text { Blocked voltage-sensitive } \mathrm{Na}^{+} \text {channels }\left(\mathrm{IC}_{50}=60 \mu \mathrm{M} \text { for genistein and }\right. \\
195 \mu \mathrm{M} \text { for daidzein) }\end{array}$ & [72] \\
\hline \multicolumn{5}{|l|}{ Stilbenoid } \\
\hline Resveratrol & LA & In vitro: Measurement of $\mathrm{Na}^{+}$currents in rat dorsal root ganglion neurons & $\begin{array}{l}\text { Suppressed tetrodotoxin-sensitive and tetrodotoxin-resistant } \\
\mathrm{Na}^{+} \text {channels }\end{array}$ & [75] \\
\hline \multicolumn{5}{|l|}{ Terpenoids } \\
\hline Aristolen-1(10)-en-9-ol & $\begin{array}{c}\mathrm{S} \\
\mathrm{H} \\
\text { GA-like }\end{array}$ & In vivo: Spontaneous vapor administration to mice & $\begin{array}{l}\text { Inhibited the locomotion of caffeine-treated mice at } 300 \mu \mathrm{g} / \mathrm{cage} \text { and } \\
\text { prolonged the time of pentobarbital-induced sleep } \\
\text { The effects were inhibited by flumazenil }\end{array}$ & [89] \\
\hline $\begin{array}{l}\text { Isopulegol } \\
\text { Pinocarveol } \\
\text { Verbenol } \\
\text { Myrtenol }\end{array}$ & GA-like & $\begin{array}{l}\text { In vitro: Determination of the effects on } \mathrm{GABA}_{\mathrm{A}} \text { receptor } \alpha 1 \beta 2 \text { or } \alpha 1 \beta 2 \gamma 2 \\
\text { subunits expressed in Xenopus laevis oocytes or human embryonic } \\
\text { kidney cells }\end{array}$ & $\begin{array}{l}\text { Modulated } \mathrm{GABA}_{\mathrm{A}} \text { receptor functions at } 3-300 \mu \mathrm{M} \text { independently of the } \\
\gamma 2 \text { subunit }\end{array}$ & [92] \\
\hline
\end{tabular}


Table 1. Cont

\begin{tabular}{|c|c|c|c|c|}
\hline Phytochemicals & Activities & Experiments & Results & References \\
\hline Valerenic acid & GA-like & $\begin{array}{l}\text { In vitro: Determination of the effect on } \mathrm{GABA}_{\mathrm{A}} \text { receptors in neonatal rat } \\
\text { brainstem preparations }\end{array}$ & $\begin{array}{l}\text { Inhibited muscimol-sensitive neurons }\left(\mathrm{IC}_{50}=23 \mu \mathrm{M}\right) \\
\text { The effect was antagonized by bicuculline }\end{array}$ & [93] \\
\hline Valerenic acid & $\begin{array}{l}\text { GA-like } \\
\text { A }\end{array}$ & $\begin{array}{l}\text { In vitro and in vivo: Radioligand binding assay with crude rat brain } \\
\text { membranes and } 1-6 \mathrm{mg} / \mathrm{kg} \text { (i.p.) and } 10 \mathrm{mg} / \mathrm{kg} \text { (p.o.) } \\
\text { administration to mice }\end{array}$ & $\begin{array}{l}\text { Interacted allosterically with benzodiazepine and GABA binding site of } \\
\text { GABA }_{\mathrm{A}} \text { receptors } \\
\text { Showed anxiolytic effects on mice }\end{array}$ & [96] \\
\hline Linalool & $\begin{array}{c}\mathrm{S} \\
\mathrm{H} \\
\text { GA-like }\end{array}$ & $\begin{array}{l}\text { In vivo: Placed mice in a chamber of an atomosphere saturated } \\
1 \% \text { or } 3 \% \text { vapor }\end{array}$ & Produced sedation and increased the time of pentobarbital-induced sleep & [99] \\
\hline Menthol & GA-like & $\begin{array}{l}\text { In vitro: Determination of the effect on recombinant human } \mathrm{GABA}_{\mathrm{A}} \\
\text { receptors expressed in Xenopus laevis oocytes }\end{array}$ & Enhanced sub-maximal GABA currents at 3-300 $\mu \mathrm{M}$ & [102] \\
\hline Menthol & GA-like & $\begin{array}{l}\text { In vitro: Whole-cell voltage clamp recording of rat midbrain } \\
\text { periaqueductal grey neurons }\end{array}$ & $\begin{array}{l}\text { Prolonged at } 150-750 \mu \mathrm{M} \text { the duration of spontaneous inhibitory } \\
\text { postsynaptic potentials mediated by GABA } A_{A} \text { receptors }\end{array}$ & [103] \\
\hline $\begin{array}{l}\text { Thymol } \\
\text { Carvacrol } \\
\text { Eugenol }\end{array}$ & GA-like & $\begin{array}{l}\text { In vitro: Determination of the effects on primary cultures of mouse cortical } \\
\text { neurons at micromolar concentrations }\end{array}$ & $\begin{array}{l}\left.\text { Enhanced }{ }^{3} \mathrm{H}\right] \text { flunitrazepam binding to } \mathrm{GABA}_{\mathrm{A}} \text { receptors and increased } \\
2 \mu \mathrm{M} \mathrm{GABA} \text {-evoked } \mathrm{Cl}^{-} \text {influx }\end{array}$ & [15] \\
\hline Thymol & GA-like & $\begin{array}{l}\text { In vitro: Determination of the effects on human } \mathrm{GABA}_{\mathrm{A}} \text { receptor subunit } \\
\text { combinations expressed in Xenopus laevis oocytes }\end{array}$ & Potentiated $\mathrm{EC}_{20} \mathrm{GABA}$ response at $1-100 \mu \mathrm{M}$ & [104] \\
\hline Thymol & GA-like & $\begin{array}{l}\text { In vitro: Determination of the positive allosteric modulatory effects on } \\
\mathrm{GABA}_{\mathrm{A}} \text { receptors in primary cultures of mouse cortical neurons }\end{array}$ & $\begin{array}{l}\text { Enhanced } 5 \mu \mathrm{M} \text { GABA-induced } \mathrm{Cl}^{-} \text {influx }\left(\mathrm{EC}_{50}=12 \mu \mathrm{M}\right) \text { and directly } \\
\text { enhanced } \mathrm{Cl}^{-} \text {influx }\left(\mathrm{EC}_{50}=135 \mu \mathrm{M}\right)\end{array}$ & [14] \\
\hline \multicolumn{5}{|l|}{ Alkaloids } \\
\hline Harman & $\begin{array}{l}\text { A } \\
\mathrm{S}\end{array}$ & In vivo: $2.5-10 \mathrm{mg} / \mathrm{kg}$ (i.p.) administration to rats & $\begin{array}{l}\text { Decreased the time of immobility in a forced swim test and increased the } \\
\text { time spent in open arms in an elevated plus maze }\end{array}$ & [110] \\
\hline $\begin{array}{l}\text { Harman } \\
\text { Norharman } \\
\text { Harmine }\end{array}$ & $\begin{array}{c}\mathrm{S} \\
\text { GA-like }\end{array}$ & In vivo: $2.5-15 \mathrm{mg} / \mathrm{kg}$ (i.p.) administration to mice & $\begin{array}{l}\text { Decreased the time of immobility } \\
\text { The effects were inhibited by flumazenil }\end{array}$ & [111] \\
\hline \multicolumn{5}{|l|}{ Flavonoids } \\
\hline $\begin{array}{l}\text { (-)-Epigallo-catechin- } \\
\text { 3-gallate }\end{array}$ & $\mathrm{H}$ & In vivo: $5-20 \mathrm{mg} / \mathrm{kg}$ (p.o.) administration to mice & Prolonged the time of pentobarbital-induced sleep & [117] \\
\hline Apigenin & $\begin{array}{c}\mathrm{S} \\
\text { GA-like }\end{array}$ & In vivo: $0.6 \mathrm{mg} / \mathrm{kg}$ (p.o.) administration to mice & $\begin{array}{l}\text { Induced sedation } \\
\text { The effect was blocked by flumazenil }\end{array}$ & [120] \\
\hline Chrysin & $\begin{array}{c}\text { A } \\
\text { GA-like }\end{array}$ & In vivo: $2 \mathrm{mg} / \mathrm{kg}$ (i.p.) administration to rats & $\begin{array}{l}\text { Induced anxiolysis } \\
\text { The effect was affected by flumazenil }\end{array}$ & [121] \\
\hline Baicalein Baicalin & $\begin{array}{c}\text { A } \\
\text { GA-like }\end{array}$ & In vivo: $10-20 \mathrm{mg} / \mathrm{kg}$ (i.p.) administration to mice & $\begin{array}{l}\text { Induced anxiolysis } \\
\text { The effects were antagonized by flumazenil }\end{array}$ & [123] \\
\hline Kaempferol & $\begin{array}{c}\text { A } \\
\text { GA-like }\end{array}$ & In vivo: $0.02-1.0 \mathrm{mg} / \mathrm{kg}$ (p.o.) administration to mice & $\begin{array}{l}\text { Induced anxiolysis } \\
\text { The effect was antagonized by flumazenil }\end{array}$ & [124] \\
\hline
\end{tabular}


Table 1. Cont

\begin{tabular}{|c|c|c|c|c|}
\hline Phytochemicals & Activities & Experiments & Results & References \\
\hline Wogonin & $\begin{array}{l}\text { GA-like } \\
\text { A }\end{array}$ & $\begin{array}{l}\text { In vitro and in vivo: Radioreceptor binding assay with rat forebrain } \\
\text { synaptosomal membranes, electrophysiological experiment with rat dorsal } \\
\text { root ganglion neurons and } 7.5-30 \mathrm{mg} / \mathrm{kg} \text { (p.o.) administration to mice }\end{array}$ & $\begin{array}{l}\text { Showed the affinity for the benzodiazepine site of } \mathrm{GABA}_{\mathrm{A}} \text { receptors } \\
(\mathrm{Ki}=0.92 \mu \mathrm{M}) \text {, enhanced GABA-activated currents and } \\
\text { induced anxiolysis }\end{array}$ & [125] \\
\hline Isoliquiritigenin & $\begin{array}{l}\text { GA-like } \\
\text { H }\end{array}$ & $\begin{array}{l}\text { In vitro and in vivo: Radioreceptor binding assay with rat cerebral cortex } \\
\text { membranes, electrical measurement of rat dorsal raphe neurons and } \\
25-50 \mathrm{mg} / \mathrm{kg} \text { (p.o.) administration to mice }\end{array}$ & $\begin{array}{l}\text { Showed the affinity for } \mathrm{GABA}_{\mathrm{A}} \text {-benzodiazepine receptors }(K i=0.45 \mu \mathrm{M}) \text {, } \\
\text { increased GABA-evoked currents and potentiated } \\
\text { pentobarbital-induced sleep }\end{array}$ & [128] \\
\hline Isoliquiritigenin & GA-like & $\begin{array}{l}\text { In vitro: Measurement of the GABAergic synaptic renponses by the } \\
\text { whole-cell patch clamp technique }\end{array}$ & $\begin{array}{l}\text { Prolonged at } 1 \mu \mathrm{M} \text { the decay of spontaneous inhibitory postsynaptic } \\
\text { currents mediated by GABA } \mathrm{A}_{\mathrm{A}} \text { receptors } \\
\text { The effect was inhibited by flumazenil }\end{array}$ & [129] \\
\hline Glabrol & $\begin{array}{c}\mathrm{H} \\
\text { GA-like }\end{array}$ & In vivo: $25-50 \mathrm{mg} / \mathrm{kg}$ (p.o.) administration to mice & $\begin{array}{l}\text { Increased the sleep duration and decreased the sleep latency in mice } \\
\text { treated with pentobarbital } \\
\text { The effects were blocked by flumazenil }\end{array}$ & [131] \\
\hline Apigenin & A & $\begin{array}{l}\text { Pre-clinical: Randomized, double-blind, placebo-controlled trial for } \\
\text { outpatients with } 220 \mathrm{mg} \text { chamomile extracts standardized to a content of } \\
1.2 \% \text { apigenin }\end{array}$ & $\begin{array}{l}\text { Showed clinically meaningful difference from controls in anxiety } \\
\text { rating scores }\end{array}$ & [149] \\
\hline $\begin{array}{l}\text { Wogonin } \\
\text { Baicalein } \\
\text { Baicalin } \\
\text { Scutellarein }\end{array}$ & A & $\begin{array}{l}\text { Pre-clinical: Double-blind and placebo-controlled study for human } \\
\text { subjects with 100-200 mg skullcap extracts containing flavones }\end{array}$ & Exhibited anxiolytic effects & {$[150,151]$} \\
\hline
\end{tabular}

LA: local anesthetic; GA: general anesthetic; AA: antinociceptive/analgesic; S: sedative; A: anxiolytic; H: hypnotic. 
Acknowledgments: This study was supported by Grants-in-Aid for Scientific Research (C) 26463078 and Scientific Research (C) 17K11924 from the Japan Society for the Promotion of Science.

Author Contributions: Hironori Tsuchiya designed and performed the research, and wrote the manuscript.

Conflicts of Interest: The author declares there are no conflicts of interest in this study.

\section{Abbreviations}

The following abbreviations are used in this manuscript:

CAP Compound action potential

$\mathrm{GABA}_{\mathrm{A}}$ receptor $\quad \gamma$-aminobutyric acid type A receptor

Nav channel Voltage-gated $\mathrm{Na}^{+}$channel

NMDA receptor $\quad N$-methyl-D-aspartate receptor

TTX Tetrodotoxin

\section{References}

1. Butler, M.S. The role of natural product chemistry in drug discovery. J. Nat. Prod. 2004, 67, $2141-2153$. [CrossRef] [PubMed]

2. Newman, D.J.; Cragg, G.M. Natural products as sources of new drugs and over the 30 years from 1981 to 2010. J. Nat. Prod. 2012, 75, 311-335. [CrossRef] [PubMed]

3. Chidiac, E.J.; Kaddoum, R.N.; Fuleihan, S.F. Mandragora: Anesthetic of the ancients. Anesth. Analg. 2012, 115, 1437-1441. [CrossRef] [PubMed]

4. Fabricant, D.S.; Farnsworth, N.R. The value of plants used in traditional medicine for drug discovery. Environ. Health Perspect. 2001, 109, 69-75. [CrossRef] [PubMed]

5. Jachak, S.M.; Saklani, A. Challenges and opportunities in drug discovery from plants. Curr. Sci. 2007, 92, 1251-1257.

6. Grémiaux, A.; Yokawa, K.; Mancuso, S.; Baluška, F. Plant anesthesia supports similarities between animals and plants: Claude Bernard's forgotten studies. Plant Signal. Behav. 2014, 9, e27886. [CrossRef] [PubMed]

7. Baluška, F.; Yokawa, K.; Mancuso, S.; Baverstock, K. Understanding of anesthesia-Why consciousness is essential for life and not based on genes. Commun. Integr. Biol. 2016, 9, e1238118. [CrossRef] [PubMed]

8. Calatayud, J.; González, Á. History of the development and evolution of local anesthesia since the coca leaf. Anesthesiology 2003, 98, 1503-1508. [CrossRef] [PubMed]

9. Koller, C. The sub-conjunctival application of cocaine in eye operations. Trans. Am. Ophthalmol. Soc. 1892, 6, 421-424. [PubMed]

10. Fozzard, H.A.; Lee, P.J.; Lipkind, G.M. Mechanism of local anesthetic drug action on voltage-gated sodium channels. Curr. Pharm. Des. 2005, 11, 2671-2686. [CrossRef] [PubMed]

11. Tsuchiya, H.; Mizogami, M. Interaction of local anesthetics with biomembranes consisting of phospholipids and cholesterol: Mechanistic and clinical implications for anesthetic and cardiotoxic effects. Anesthesiol. Res. Pract. 2013, 2013, 297141. [CrossRef] [PubMed]

12. James, R.; Glen, J.B. Synthesis, biological evaluation, and preliminary structure-activity considerations of a series of alkylphenols as intravenous anesthetic agent. J. Med. Chem. 1980, 23, 1350-1357. [CrossRef] [PubMed]

13. Kay, B.; Stephenson, D.K. ICI 35868 (Diprivan): A new intravenous anaesthetic. A comparison with Althesin. Anaesthesia 1980, 35, 1182-1187. [CrossRef] [PubMed]

14. García, D.A.; Bujons, J.; Vale, C.; Suñol, C. Allosteric positive interaction of thymol with the GABA $\mathrm{A}_{\mathrm{A}}$ receptor in primary cultures of mouse cortical neurons. Neuropharmacology 2006, 50, 25-35. [CrossRef] [PubMed]

15. Reiner, G.N.; Delgado-Marín, L.; Olguín, N.; Sánchez-Redondo, S.; Sánchez-Borzone, M.; Rodríguez-Farré, E.; Suñol, C.; García, D.A. Gabaergic pharmacological activity of propofol related compounds as possible enhancers of general anesthetics and interaction with membranes. Cell Biochem. Biophys. 2013, 67, 515-525. [CrossRef] [PubMed]

16. Tsuchiya, H. Structure-specific membrane-fluidizing effect of propofol. Clin. Exp. Pharmacol. Physiol. 2001, 28, 292-299. [CrossRef] [PubMed] 
17. Reiner, G.N.; Fraceto, L.F.; de Paula, E.; Perillo, M.A.; García, D.A. Effects of gabaergic phenols on phospholipid bilayers as evaluated by ${ }^{1} \mathrm{H}-\mathrm{NMR}$. J. Biomater. Nanobiotechnol. 2013, 4, 28-34. [CrossRef]

18. Catterall, W.A. Voltage-gated sodium channels at 60: Structure, function and pathophysiology. J. Physiol. 2012, 590, 2577-2589. [CrossRef] [PubMed]

19. Krishnakumar, S.; Geetha, V.S.; Kuruvilla, A. Determination of local anesthetic action of Betel leaf extract alone and with Betel nut using infiltration and surface anesthesia. J. Nat. Rem. 2001, 1, 28-32. [CrossRef]

20. Abdulrahman, F.I.; Onyeyili, P.A.; Sandabe, U.K.; Ogugbuaja, V.O. Evaluation of the effects of the aqueous extract of Vitex doniana root-bark on the peripheral and central nervous system of laboratory animals. J. Appl. Sci. 2007, 7, 1397-1403. [CrossRef]

21. Tijjani, M.A.; Abdulrahman, F.I.; Khan, I.Z.; Sandabe, U.K. The effects of ethanolic extract of Vitex doniana stem bark on peripheral and central nervous system of laboratory animals. J. Appl. Pharm. Sci. 2012, 2, 74-79. [CrossRef]

22. Chakraborty, A.; Devi, B.R.; Sanjebam, R.; Khumbong, S.; Thokchom, I.S. Preliminary studies on local anesthetic and antipyretic activities of Spilanthes acmella Murr. in experimental animal models. Indian J. Pharmacol. 2010, 42, 277-279. [CrossRef] [PubMed]

23. Udegbunam, R.I.; Asuzu, U.I.; Kene, R.O.; Udegbunam, S.O.; Nwaehujor, C.O. Local anesthetic and tissue effects of the leaf extract and fractions of Sterculia tragacantha Lindl. J. Pharmacol. Toxicol. 2012, 7, 192-198. [CrossRef]

24. Udegbunam, R.I.; Asuzu, U.I.; Kene, R.O.; Udegbunam, S.O. Evaluation of local anesthetic efficacy of the crude extract of Sterculia tragacantha using West African Dwarf goats. Sokoto J. Vet. Sci. 2013, 11, 13-21. [CrossRef]

25. De Sousa, D.P. Analgesic-like activity of essential oils constituents. Molecules 2011, 16, 2233-2252. [CrossRef] [PubMed]

26. Guimarães, A.G.; Quintans, J.S.; Quintans, L.J., Jr. Monoterpenes with analgesic activity-A systematic review. Phytother. Res. 2013, 27, 1-15. [CrossRef] [PubMed]

27. Djilani, A.; Dicko, A. The therapeutic benefits of essential oils. In Nutrition, Well-being and Health; Bouayed, J., Bohn, T., Eds.; InTech: Shanghai, China, 2012; pp. 155-178. [CrossRef]

28. Oz, M.; Lozon, Y.; Sultan, A.; Yang, K.H.; Galadari, S. Effects of monoterpenes on ion channels of excitable cells. Pharmacol. Ther. 2015, 152, 83-97. [CrossRef] [PubMed]

29. Zalachoras, I.; Kagiava, A.; Vokou, D.; Theophilidis, G. Assessing the local anesthetic effect of five essential oil constituents. Planta Med. 2010, 76, 1647-1653. [CrossRef] [PubMed]

30. Ghelardini, C.; Galeotti, N.; Salvatore, G.; Mazzanti, G. Local anaesthetic activity of the essential oil of Lavandula angustifolia. Planta Med. 1999, 65, 700-703. [CrossRef] [PubMed]

31. Leal-Cardoso, J.H.; da Silva-Alves, K.S.; Ferreira-da-Silva, F.W.; dos Santos-Nascimento, T.; Joca, H.C.; de Macedo, F.H.; de Albuquerque-Neto, P.M.; Magalhães, P.J.; Lahlou, S.; Cruz, J.S.; et al. Linalool blocks excitability in peripheral nerves and voltage-dependent $\mathrm{Na}^{+}$current in dissociated dorsal root ganglia neurons. Eur. J. Pharmacol. 2010, 645, 86-93. [CrossRef] [PubMed]

32. Peana, A.T.; D’Aquila, P.S.; Panin, F.; Serra, G.; Pippia, P.; Moretti, M.D. Anti-inflammatory activity of linalool and linalyl acetate constituents of essential oils. Phytomedicine 2002, 9, 721-726. [CrossRef] [PubMed]

33. Galeotti, N.; Ghelardini, C.; Mannelli, L.; Mazzanti, G.; Baghiroli, L.; Bartolini, A. Local anaesthetic activity of (+)- and (-)-menthol. Planta Med. 2001, 67, 174-176. [CrossRef] [PubMed]

34. Gaudioso, C.; Hao, J.; Martin-Eauclaire, M.F.; Gabriac, M.; Delmas, P. Menthol pain relief through cumulative inactivation of voltage-gated sodium channels. Pain 2012, 153, 473-484. [CrossRef] [PubMed]

35. Pan, R.; Tian, Y.; Gao, R.; Li, H.; Zhao, X.; Barrett, J.E.; Hu, H. Central mechanisms of menthol-induced analgesia. J. Pharmacol. Exp. Ther. 2012, 343, 661-672. [CrossRef] [PubMed]

36. Kawasaki, H.; Mizuta, K.; Fujita, T.; Kumamoto, E. Inhibition by menthol and its related chemicals of compound action potentials in frog sciatic nerves. Life Sci. 2013, 92, 359-367. [CrossRef] [PubMed]

37. Tomohiro, D.; Mizuta, K.; Fujita, T.; Nishikubo, Y.; Kumamoto, E. Inhibition by capsaicin and its related vanilloids of compound action potentials in frog sciatic nerves. Life Sci. 2013, 92, 368-378. [CrossRef] [PubMed]

38. Ohtsubo, S.; Fujita, T.; Matsushita, A.; Kumamoto, E. Inhibition of the compound action potentials of frog sciatic nerves by aroma oil compounds having various chemical structures. Pharmacol. Res. Perspect. 2015, 3, e00127. [CrossRef] [PubMed] 
39. Katsuki, R.; Fujita, T.; Koga, A.; Liu, T.; Nakatsuka, T.; Nakashima, M.; Kumamoto, E. Tramadol, but not its major metabolite (mono-O-demethyl tramadol) depresses compound action potentials in frog sciatic nerves. Br. J. Pharmacol. 2006, 149, 319-327. [CrossRef] [PubMed]

40. Mizuta, K.; Fujita, T.; Nakatsuka, T.; Kumamoto, E. Inhibitory effects of opioids on compound action potentials in frog sciatic nerves and their chemical structures. Life Sci. 2008, 83, 198-207. [CrossRef] [PubMed]

41. Uemura, Y.; Fujita, T.; Ohtsubo, S.; Hirakawa, N.; Sakaguchi, Y.; Kumamoto, E. Effects of various antiepileptics used to alleviate neuropathic pain on compound action potential in frog sciatic nerves: Comparison with those of local anesthetics. Biomed. Res. Int. 2014, 2014, 540238. [CrossRef] [PubMed]

42. Joca, H.C.; Cruz-Mendes, Y.; Oliveira-Abreu, K.; Maia-Joca, R.P.; Barbosa, R.; Lemos, T.L.; Lacerda Beirão, P.S.; Leal-Cardoso, J.H. Carvacrol decreases neuronal excitability by inhibition of voltage-gated sodium channels. J. Nat. Prod. 2012, 75, 1511-1517. [CrossRef] [PubMed]

43. Cavalcante Melo, F.H.; Rios, E.R.; Rocha, N.F.; Citó Mdo, C.; Fernandes, M.L.; de Sousa, D.P.; de Vasconcelos, S.M.; de Sousa, F.C. Antinociceptive activity of carvacrol (5-isopropyl-2-methylphenol) in mice. J. Pharm. Pharmacol. 2012, 64, 1722-1729. [CrossRef] [PubMed]

44. Gonçalves, J.C.; de Sousa Oliveira, F.; Benedito, R.B.; de Sousa, D.P.; de Almeida, R.N.; de Araújo, D.A. Antinociceptive activity of (-)-carvone: Evidence of association with decreased peripheral nerve excitability. Biol. Pharm. Bull. 2008, 31, 1017-1020. [CrossRef] [PubMed]

45. Leal-Cardoso, J.H.; Matos-Brito, B.G.; Lopes-Junior, J.E.; Viana-Cardoso, K.V.; Sampaio-Freitas, A.B.; Brasil, R.O.; Coelho-De-Souza, A.N.; Albuquerque, A.A. Effects of estragole on the compound action potential of the rat sciatic nerve. Braz. J. Med. Biol. Res. 2004, 37, 1193-1198. [CrossRef] [PubMed]

46. Silva-Alves, K.S.; Ferreira-da-Silva, F.W.; Peixoto-Neves, D.; Viana-Cardoso, K.V.; Moreira-Júnior, L.; Oquendo, M.B.; Oliveira-Abreu, K.; Albuquerque, A.A.; Coelho-de-Souza, A.N.; Leal-Cardoso, J.H. Estragole blocks neuronal excitability by direct inhibition of $\mathrm{Na}^{+}$channels. Braz. J. Med. Biol. Res. 2013, 46, 1056-1063. [CrossRef] [PubMed]

47. Da Silva-Alves, K.S.; Ferreira-da-Silva, F.W.; Coelho-de-Souza, A.N.; Albuquerque, A.A.; do Vale, O.C.; Leal-Cardoso, J.H. Essential oil of Croton zehntneri and its main constituent anethole block excitability of rat peripheral nerve. Planta Med. 2015, 81, 292-297. [CrossRef] [PubMed]

48. Sousa, D.G.; Sousa, S.D.; Silva, R.E.; Silva-Alves, K.S.; Ferreira-da-Silva, F.W.; Kerntopf, M.R.; Menezes, I.R.; Leal-Cardoso, J.H.; Barbosa, R. Essential oil of Lippia alba and its main constituent citral block the excitability of rat sciatic nerves. Braz. J. Med. Biol. Res. 2015, 48, 697-702. [CrossRef] [PubMed]

49. Lima-Accioly, P.M.; Lavor-Porto, P.R.; Cavalcante, F.S.; Magalhães, P.J.; Lahlou, S.; Morais, S.M.; Leal-Cardoso, J.H. Essential oil of Croton nepetaefolius and its main constituent, 1,8-cineole, block excitability of rat sciatic nerve in vitro. Clin. Exp. Pharmacol. Physiol. 2006, 33, 1158-1163. [CrossRef] [PubMed]

50. Ferreira-da-Silva, F.W.; Barbosa, R.; Moreira-Júnior, L.; dos Santos-Nascimento, T.; de Oliveira-Martins, M.D.; Coelho-de-Souza, A.N.; Cavalcante, F.S.; Ceccatto, V.M.; de Lemos, T.L.; Magalhães, P.J.; et al. Effects of 1,8-cineole on electrophysiological parameters of neurons of the rat superior cervical ganglion. Clin. Exp. Pharmacol. Physiol. 2009, 36, 1068-1073. [CrossRef] [PubMed]

51. Ghelardini, C.; Galeotti, N.; Mazzanti, G. Local anaesthetic activity of monoterpenes and phenylpropanes of essential oils. Planta Med. 2001, 67, 564-566. [CrossRef] [PubMed]

52. Quintans-Júnior, L.; Moreira, J.C.; Pasquali, M.A.; Rabie, S.M.; Pires, A.S.; Schröder, R.; Rabelo, T.K.; Santos, J.P.; Lima, P.S.; Cavalcanti, S.C.; et al. Antinociceptive activity and redox profile of the monoterpenes (+)-camphene, p-cymene, and geranyl acetate in experimental models. ISRN Toxicol. 2013, 2013, 459530. [CrossRef] [PubMed]

53. Dolara, P.; Corte, B.; Ghelardini, C.; Pugliese, A.M.; Cerbai, E.; Menichetti, S.; Lo Nostro, A. Local anaesthetic, antibacterial and antifungal properties of sesquiterpenes from myrrh. Planta Med. 2000, 66, 356-358. [CrossRef] [PubMed]

54. Ghelardini, C.; Galeotti, N.; Di Cesare Mannelli, L.; Mazzanti, G.; Bartolini, A. Local anaesthetic activity of $\beta$-caryophyllene. Farmaco 2001, 56, 387-389. [CrossRef] [PubMed]

55. Mendanha, S.A.; Moura, S.S.; Anjos, J.L.; Valadares, M.C.; Alonso, A. Toxicity of terpenes on fibroblast cells compared to their hemolytic potential and increase in erythrocyte membrane fluidity. Toxicol. In Vitro 2013, 27, 323-329. [CrossRef] [PubMed] 
56. Yin, Q.; Shi, X.; Ding, H.; Dai, X.; Wan, G.; Qiao, Y. Interactions of borneol with DPPC phospholipid membranes: A molecular dynamics simulation study. Int. J. Mol. Sci. 2014, 15, 20365-20381. [CrossRef] [PubMed]

57. Nowotarska, S.W.; Nowotarski, K.J.; Friedman, M.; Situ, C. Effect of structure on the interactions between five natural antimicrobial compounds and phospholipids of bacterial cell membrane on model monolayers. Molecules 2014, 19, 7497-7515. [CrossRef] [PubMed]

58. Tsuchiya, H.; Mizogami, M. Comparative interactions of anesthetic alkylphenols with lipid membranes. Open J. Anesthesiol. 2014, 4, 308-317. [CrossRef]

59. Sarmento-Neto, J.F.; do Nascimento, L.G.; Felipe, C.F.; de Sousa, D.P. Analgesic potential of essential oils. Molecules 2016, 21, 20. [CrossRef] [PubMed]

60. Vadhanan, C.P.; Narendren, G. Future local anesthetics-Neurotoxins? Int. J. Anesthesiol. Res. 2014, 2, 11-15. [CrossRef]

61. Dzhakhangirov, F.N.; Kasymova, K.R.; Sultankhodzhaev, M.N.; Salimov, B.T.; Usmanova, S.K.; Shakirov, R.S. Toxicity and local anesthetic activity of diterpenoid alkaloids. Chem. Nat. Compd. 2007, 43, 581-589. [CrossRef]

62. Wright, S.N. Irreversible block of human heart $(\mathrm{hH1})$ sodium channels by the plant alkaloid lappaconitine. Mol. Pharmacol. 2001, 59, 183-192. [CrossRef] [PubMed]

63. Gutser, U.T.; Friese, J.; Heubach, J.F.; Matthiesen, T.; Selve, N.; Wilffert, B.; Gleitz, J. Mode of antinociceptive and toxic action of alkaloids of Aconitum spec. Naunyn Schmiedebergs Arch. Pharmacol. 1998, 357, $39-48$. [CrossRef] [PubMed]

64. Wang, Y.Z.; Xiao, Y.Q.; Zhang, C.; Sun, X.M. Study of analgesic and anti-inflammatory effects of lappaconitine gelata. J. Tradit. Chin. Med. 2009, 29, 141-145. [CrossRef]

65. Wang, C.F.; Gerner, P.; Wang, S.Y.; Wang, G.K. Bulleyaconitine A isolated from Aconitum plant displays long-acting local anesthetic properties in vitro and in vivo. Anesthesiology 2007, 107, 82-90. [CrossRef] [PubMed]

66. Wang, C.F.; Gerner, P.; Schmidt, B.; Xu, Z.Z.; Nau, C.; Wang, S.Y.; Ji, R.R.; Wang, G.K. Use of bulleyaconitine A as an adjuvant for prolonged cutaneous analgesia in the rat. Anesth. Analg. 2008, 107, 1397-1405. [CrossRef] [PubMed]

67. Turabekova, M.A.; Rasulev, B.F.; Dzhakhangirov, F.N.; Toropov, A.A.; Leszczynska, D.; Leszczynski, J. Aconitum and Delphinium diterpenoid alkaloids of local anesthetic activity: Comparative QSAR analysis based on GA-MLRA/PLS and optimal descriptors approach. J. Environ. Sci. Health C Environ. Carcinog. Ecotoxicol. Rev. 2014, 32, 213-238. [CrossRef] [PubMed]

68. Tsuchiya, H. Biphasic effects of acetaldehyde-biogenic amine condensation products on membrane fluidity. J. Pharm. Pharmacol. 2001, 53, 121-127. [CrossRef] [PubMed]

69. Tsuchiya, H.; Mizogami, M. Drinking-related tetrahydroharmans counteract the membrane effects of local anesthetic lidocaine. J. Drug Alcohol Res. 2014, 3, 235887. [CrossRef]

70. Wu, Y.L.; Ohsaga, A.; Oshiro, T.; Iinuma, K.; Kondo, Y.; Ebihara, S.; Sasaki, H.; Maruyama, Y. Suppressive effects of red wine polyphenols on voltage-gated ion channels in dorsal root ganglionic neuronal cells. Tohoku J. Exp. Med. 2005, 206, 141-150. [CrossRef] [PubMed]

71. Kim, T.H.; Lim, J.M.; Kim, S.S.; Kim, J.; Park, M.; Song, J.H. Effects of (-)epigallocatechin-3-gallate on $\mathrm{Na}^{+}$ currents in rat dorsal root ganglion neurons. Eur. J. Pharmacol. 2009, 604, 20-26. [CrossRef] [PubMed]

72. Paillart, C.; Carlier, E.; Guedin, D.; Dargent, B.; Couraud, F. Direct block of voltage-sensitive sodium channels by genistein, a tyrosine kinase inhibitor. J. Pharmacol. Exp. Ther. 1997, 280, 521-526. [PubMed]

73. Adaramoye, O.A. Protective effect of kolaviron, a bioflavonoid from Garcinia kola seeds, in brain of Wistar albino rats exposed to gamma-radiation. Biol. Pharm. Bull. 2010, 33, 260-266. [CrossRef] [PubMed]

74. Tchimene, M.K.; Aanaga, A.O.; Ugwoke, C.E.; Ezugu, C.O.; Okunji, C.; Iwu, M.M. Bio-flavonoids and garcinoic acid from Garcinia kola seeds with promising local anesthetic potentials. Int. J. Pharmacogn. Phytochem. Res. 2015, 7, 764-767.

75. Kim, H.I.; Kim, T.H.; Song, J.H. Resveratrol inhibits $\mathrm{Na}^{+}$currents in rat dorsal root ganglion neurons. Brain Res. 2005, 1045, 134-141. [CrossRef] [PubMed]

76. Chau, P.L. New insights into the molecular mechanisms of general anaesthetics. Br. J. Pharmacol. 2010, 161, 288-307. [CrossRef] [PubMed]

77. Olsen, R.W.; Li, G.D. GABA A receptors as molecular targets of general anesthetics: Identification of binding sites provides clues to allosteric modulation. Can. J. Anaesth. 2011, 58, 206-215. [CrossRef] [PubMed] 
78. Tsuchiya, H. Membrane interactions of phytochemicals as their molecular mechanism applicable to the discovery of drug leads from plants. Molecules 2015, 20, 18923-18966. [CrossRef] [PubMed]

79. Tsang, S.Y.; Xue, H. Development of effective therapeutics targeting the $\mathrm{GABA}_{\mathrm{A}}$ receptor: Naturally occurring alternatives. Curr. Pharm. Des. 2004, 10, 1035-1044. [CrossRef] [PubMed]

80. Zaku, S.G.; Abdulrahaman, F.A.; Onyeyili, P.A.; Aguzue, O.C.; Thomas, S.A. Phytochemical constituents and effects of aqueous root-bark extract of Ficus sycomorus L. (Moraceae) on muscular relaxation, anaesthetic and sleeping time on laboratory animals. Afr. J. Biotechnol. 2009, 8, 6004-6006.

81. Grundmann, O.; Wang, J.; McGregor, G.P.; Butterweck, V. Anxiolytic activity of a phytochemically characterized Passiflora incarnata extract is mediated via the GABAergic system. Planta Med. 2008, 74, 1769-1773. [CrossRef] [PubMed]

82. Appel, K.; Rose, T.; Fiebich, B.; Kammler, T.; Hoffmann, C.; Weiss, G. Modulation of the $\gamma$-aminobutyric acid (GABA) system by Passiflora incarnata L. Phytother. Res. 2011, 25, 838-843. [CrossRef] [PubMed]

83. Lolli, L.F.; Sato, C.M.; Romanini, C.V.; de Villas-Boas, L.B.; Santos, C.A.; de Oliveira, R.M. Possible involvement of $\mathrm{GABA}_{\mathrm{A}}$-benzodiazepine receptor in the anxiolytic-like effect induced by Passiflora actinia extracts in mice. J. Ethnopharmacol. 2007, 111, 308-314. [CrossRef] [PubMed]

84. Heldwein, C.G.; Silva, L.L.; Reckziegel, P.; Barros, F.M.; Bürger, M.E.; Baldisserotto, B.; Mallmann, C.A.; Schmidt, D.; Caron, B.O.; Heinzmann, B.M. Participation of the GABAergic system in the anesthetic effect of Lippia alba (Mill.) N.E. Brown essential oil. Braz. J. Med. Biol. Res. 2012, 45, 436-443. [CrossRef] [PubMed]

85. Parodi, T.V.; Cunha, M.A.; Heldwein, C.G.; de Souza, D.M.; Martins, Á.C.; de Garcia, L.O.; Wasielesky, W., Jr.; Monserrat, J.M.; Schmidt, D.; Caron, B.O.; et al. The anesthetic efficacy of eugenol and the essential oils of Lippia alba and Aloysia triphylla in post-larvae and sub-adults of Litopenaeus vannamei (Crustacea, Penaeidae). Comp. Biochem. Physiol. C Toxicol. Pharmacol. 2012, 155, 462-468. [CrossRef] [PubMed]

86. Silva, L.L.; Garlet, Q.I.; Benovit, S.C.; Dolci, G.; Mallmann, C.A.; Bürger, M.E.; Baldisserotto, B.; Longhi, S.J.; Heinzmann, B.M. Sedative and anesthetic activities of the essential oils of Hyptis mutabilis (Rich.) Briq. and their isolated components in silver catfish (Rhamdia quelen). Braz. J. Med. Biol. Res. 2013, 46, 771-779. [CrossRef] [PubMed]

87. Toni, C.; Becker, A.G.; Simões, L.N.; Pinheiro, C.G.; de Lima Silva, L.; Heinzmann, B.M.; Caron, B.O.; Baldisserotto, B. Fish anesthesia: Effects of the essential oils of Hesperozygis ringens and Lippia alba on the biochemistry and physiology of silver catfish (Rhamdia quelen). Fish Physiol. Biochem. 2014, 40, 701-714. [CrossRef] [PubMed]

88. Takemoto, H.; Ito, M.; Shiraki, T.; Yagura, T.; Honda, G. Sedative effects of vapor inhalation of agarwood oil and spikenard extract and identification of their active components. J. Nat. Med. 2008, 62, 41-46. [CrossRef] [PubMed]

89. Takemoto, H.; Ito, M.; Asada, Y.; Kobayashi, Y. Inhalation administration of the sesquiterpenoid aristolen-1(10)-en-9-ol from Nardostachys chinensis has a sedative effect via the GABAergic system. Planta Med. 2015, 81, 343-347. [CrossRef] [PubMed]

90. Okugawa, H.; Ueda, R.; Matsumoto, K.; Kawanishi, K.; Kato, A. Effect of jinkoh-eremol and agarospirol from agarwood on the central nervous system in mice. Planta Med. 1996, 62, 2-6. [CrossRef] [PubMed]

91. De Sousa, D.P.; de Almeida Soares Hocayen, P.; Andrade, L.N.; Andreatini, R. A systematic review of the anxiolytic-like effects of essential oils in animal models. Molecules 2015, 20, 18620-18660. [CrossRef] [PubMed]

92. Kessler, A.; Sahin-Nadeem, H.; Lummis, S.C.; Weigel, I.; Pischetsrieder, M.; Buettner, A.; Villmann, C. GABA receptor modulation by terpenoids from Sideritis extracts. Mol. Nutr. Food Res. 2014, 58, 851-862. [CrossRef] [PubMed]

93. Yuan, C.S.; Mehendale, S.; Xiao, Y.; Aung, H.H.; Xie, J.T.; Ang-Lee, M.K. The gamma-aminobutyric acidergic effects of valerian and valerenic acid on rat brainstem neuronal activity. Anesth. Analg. 2004, 98, 353-358. [CrossRef] [PubMed]

94. Khom, S.; Baburin, I.; Timin, E.; Hohaus, A.; Trauner, G.; Kopp, B.; Hering, S. Valerenic acid potentiates and inhibits $\mathrm{GABA}_{\mathrm{A}}$ receptors: Molecular mechanism and subunit specificity. Neuropharmacology 2007, 53, 178-187. [CrossRef] [PubMed]

95. Trauner, G.; Khom, S.; Baburin, I.; Benedek, B.; Hering, S.; Kopp, B. Modulation of GABAA receptors by valerian extracts is related to the content of valerenic acid. Planta Med. 2008, 74, 19-24. [CrossRef] [PubMed] 
96. Benke, D.; Barberis, A.; Kopp, S.; Altmann, K.H.; Schubiger, M.; Vogt, K.E.; Rudolph, U.; Möhler, H. GABAA receptors as in vivo substrate for the anxiolytic action of valerenic acid, a major constituent of valerian root extracts. Neuropharmacology 2009, 56, 174-181. [CrossRef] [PubMed]

97. Peana, A.T.; De Montis, M.G.; Sechi, S.; Sircana, G.; D'Aquila, P.S.; Pippia, P. Effects of (-)-linalool in the acute hyperalgesia induced by carrageenan, L-glutamate and prostaglandin E2. Eur. J. Pharmacol. 2004, 497, 279-284. [CrossRef] [PubMed]

98. Cline, M.; Taylor, J.E.; Flores, J.; Bracken, S.; McCall, S.; Ceremuga, T.E. Investigation of the anxiolytic effects of linalool, a lavender extract, in the male Sprague-Dawley rat. AANA J. 2008, 76, 47-52. [PubMed]

99. Linck, V.M.; da Silva, A.L.; Figueiró, M.; Piato, A.L.; Herrmann, A.P.; Dupont Birck, F.; Caramão, E.B.; Nunes, D.S.; Moreno, P.R.; Elisabetsky, E. Inhaled linalool-induced sedation in mice. Phytomedicine 2009, 16, 303-307. [CrossRef] [PubMed]

100. Sugawara, Y.; Hara, C.; Tamura, K.; Fujii, T.; Nakamura, K.; Masujima, T.; Aoki, T. Sedative effect on humans of inhalation of essential oil of linalool: Sensory evaluation and physiological measurements using optically active linalools. Anal. Chim. Acta 1998, 365, 293-299. [CrossRef]

101. Heldwein, C.G.; de Silva, L.L.; Gai, E.Z.; Roman, C.; Parodi, T.V.; Bürger, M.E.; Baldisserotto, B.; Flores, É.M.; Heinzmann, B.M. S-(+)-Linalool from Lippia alba: Sedative and anesthetic for silver catfish (Rhamdia quelen). Vet. Anaesth. Analg. 2014, 41, 621-629. [CrossRef] [PubMed]

102. Watt, E.E.; Betts, B.A.; Kotey, F.O.; Humbert, D.J.; Griffith, T.N.; Kelly, E.W.; Veneskey, K.C.; Gill, N.; Rowan, K.C.; Jenkins, A.; et al. Menthol shares general anesthetic activity and sites of action on the GABA receptor with the intravenous agent, propofol. Eur. J. Pharmacol. 2008, 590, 120-126. [CrossRef] [PubMed]

103. Lau, B.K.; Karim, S.; Goodchild, A.K.; Vaughan, C.W.; Drew, G.M. Menthol enhances phasic and tonic $\mathrm{GABA}_{\mathrm{A}}$ receptor-mediated currents in midbrain periaqueductal grey neurons. Br. J. Pharmacol. 2014, 171, 2803-2813. [CrossRef] [PubMed]

104. Priestley, C.M.; Williamson, E.M.; Wafford, K.A.; Sattelle, D.B. Thymol, a constituent of thyme essential oil, is a positive allosteric modulator of human $\mathrm{GABA}_{\mathrm{A}}$ receptors and a homo-oligomeric GABA receptor from Drosophila melanogaster. Br. J. Pharmacol. 2003, 140, 1363-1372. [CrossRef] [PubMed]

105. Mohammadi, B.; Haeseler, G.; Leuwer, M.; Dengler, R.; Krampfl, K.; Bufler, J. Structural requirements of phenol derivatives for direct activation of chloride currents via $\mathrm{GABA}_{\mathrm{A}}$ receptors. Eur. J. Pharmacol. 2001, 421, 85-91. [CrossRef] [PubMed]

106. Kim, S.; Ahn, K.; Oh, T.H.; Nah, S.Y.; Rhim, H. Inhibitory effect of ginsenosides on NMDA receptor-mediated signals in rat hippocampal neurons. Biochem. Biophys. Res. Commun. 2002, 296, 247-254. [CrossRef] [PubMed]

107. Lundbæk, J.A. Lipid bilayer-mediated regulation of ion channel function by amphiphilic drugs. J. Gen. Physiol. 2008, 131, 421-429. [CrossRef] [PubMed]

108. Tsuchiya, H.; Mizogami, M. Analgesic agents share the membrane interactivity possibly associated with the diversity of their pharmacological properties. Br. J. Pharm. Res. 2015, 7, 110-121. [CrossRef]

109. DeFeudis, F.V.; Drieu, K. Ginkgo biloba extract (EGb 761) and CNS functions: Basic studies and clinical applications. Curr. Drug Targets 2000, 1, 25-58. [CrossRef] [PubMed]

110. Aricioglu, F.; Altunbas, H. Harmane induces anxiolysis and antidepressant-like effects in rats. Ann. N. Y. Acad. Sci. 2003, 1009, 196-201. [CrossRef] [PubMed]

111. Farzin, D.; Mansouri, N. Antidepressant-like effect of harmane and other $\beta$-carbolines in the mouse forced swim test. Eur. Neuropsychopharmacol. 2006, 16, 324-328. [CrossRef] [PubMed]

112. Tsuchiya, H. Inhibition of membrane effects of general anesthetic propofol by benzodiazepine inverse agonist tetrahydro- $\beta$-carboline. Int. J. Pharmacol. 2012, 8, 542-548. [CrossRef]

113. Zhang, J.M.; Hu, G.Y. Huperzine A, a nootropic alkaloid, inhibits $N$-methyl-D-aspartate-induced current in rat dissociated hippocampal neurons. Neuroscience 2001, 105, 663-669. [CrossRef] [PubMed]

114. Johnston, G.A. Flavonoid nutraceuticals and ionotropic receptors for the inhibitory neurotransmitter GABA. Neurochem. Int. 2015, 89, 120-125. [CrossRef] [PubMed]

115. Jäger, A.K.; Krydsfeldt, K.; Rasmussen, H.B. Bioassay-guided isolation of apigenin with GABA-benzodiazepine activity from Tanacetum parthenium. Phytother. Res. 2009, 23, 1642-1644. [CrossRef] [PubMed]

116. Wasowski, C.; Marder, M.; Viola, H.; Medina, J.H.; Paladini, A.C. Isolation and identification of 6-methylapigenin, a competitive ligand for the brain $\mathrm{GABA}_{\mathrm{A}}$ receptors, from Valeriana wallichii. Planta Med. 2002, 68, 934-936. [CrossRef] [PubMed] 
117. Park, K.S.; Han, J.Y.; Moon, D.C.; Hong, J.T.; Oh, K.W. (-)-Epigallocatechin-3-O-gallate augments pentobarbital-induced sleeping behaviors through $\mathrm{Cl}^{-}$channel activation. J. Med. Food 2011, 14, 1456-1462. [CrossRef] [PubMed]

118. Campbell, E.L.; Chebib, M.; Johnston, G.A. The dietary flavonoids apigenin and (-)-epigallocatechin gallate enhance the positive modulation by diazepam of the activation by GABA of recombinant $\mathrm{GABA}_{\mathrm{A}}$ receptors. Biochem. Pharmacol. 2004, 68, 1631-1638. [CrossRef] [PubMed]

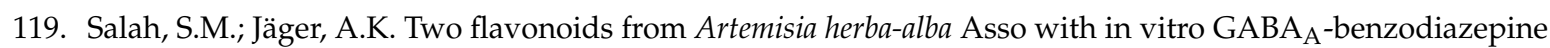
receptor activity. J. Ethnopharmacol. 2005, 99, 145-146. [CrossRef] [PubMed]

120. Gazola, A.C.; Costa, G.M.; Castellanos, L.; Ramosb, F.A.; Reginattoa, F.H.; de Limac, T.C.; Schenkel, E.P. Involvement of GABAergic pathway in the sedative activity of apigenin, the main flavonoid from Passiflora quadrangularis pericarp. Rev. Bras. Farm. 2015, 25, 158-163. [CrossRef]

121. Brown, E.; Hurd, N.S.; McCall, S.; Ceremuga, T.E. Evaluation of the anxiolytic effects of chrysin, a Passiflora incarnata extract, in the laboratory rat. AANA J. 2007, 75, 333-337. [PubMed]

122. Awad, R.; Arnason, J.T.; Trudeau, V.; Bergeron, C.; Budzinski, J.W.; Foster, B.C.; Merali, Z. Phytochemical and biological analysis of skullcap (Scutellaria lateriflora L.): A medicinal plant with anxiolytic properties. Phytomedicine 2003, 10, 640-649. [CrossRef] [PubMed]

123. Liao, J.F.; Hung, W.Y.; Chen, C.F. Anxiolytic-like effects of baicalein and baicalin in the Vogel conflict test in mice. Eur. J. Pharmacol. 2003, 464, 141-146. [CrossRef]

124. Grundmann, O.; Nakajima, J.; Kamata, K.; Seo, S.; Butterweck, V. Kaempferol from the leaves of Apocynum venetum possesses anxiolytic activities in the elevated plus maze test in mice. Phytomedicine 2009, 16, 295-302. [CrossRef] [PubMed]

125. Hui, K.M.; Huen, M.S.; Wang, H.Y.; Zheng, H.; Sigel, E.; Baur, R.; Ren, H.; Li, Z.W.; Wong, J.T.; Xue, H. Anxiolytic effect of wogonin, a benzodiazepine receptor ligand isolated from Scutellaria baicalensis Georgi. Biochem. Pharmacol. 2002, 64, 1415-1424. [CrossRef] [PubMed]

126. Hui, K.M.; Wang, X.H.; Xue, H. Interaction of flavones from the roots of Scutellaria baicalensis with the benzodiazepine site. Planta Med. 2000, 66, 91-93. [CrossRef] [PubMed]

127. Jamal, H.; Ansari, W.H.; Rizvi, S.J. Evaluation of chalcones-A flavonoid subclass, for, their anxiolytic effects in rats using elevated plus maze and open field behaviour tests. Fundam. Clin. Pharmacol. 2008, 22, 673-681. [CrossRef] [PubMed]

128. Cho, S.; Kim, S.; Jin, Z.; Yang, H.; Han, D.; Baek, N.I.; Jo, J.; Cho, C.W.; Park, J.H.; Shimizu, M.; et al. Isoliquiritigenin, a chalcone compound, is a positive allosteric modulator of $\mathrm{GABA}_{\mathrm{A}}$ receptors and shows hypnotic effects. Biochem. Biophys. Res. Commun. 2011, 413, 637-642. [CrossRef] [PubMed]

129. Woo, J.; Cho, S.; Lee, C.J. Isoliquiritigenin, a chalcone compound, enhances spontaneous inhibitory postsynaptic response. Exp. Neurobiol. 2014, 23, 163-168. [CrossRef] [PubMed]

130. Kawakami, Z.; Ikarashi, Y.; Kase, Y. Isoliquiritigenin is a novel NMDA receptor antagonist in kampo medicine yokukansan. Cell. Mol. Neurobiol. 2011, 31, 1203-1212. [CrossRef] [PubMed]

131. Cho, S.; Park, J.H.; Pae, A.N.; Han, D.; Kim, D.; Cho, N.C.; No, K.T.; Yang, H.; Yoon, M.; Lee, C.; et al. Hypnotic effects and GABAergic mechanism of licorice (Glycyrrhiza glabra) ethanol extract and its major flavonoid constituent glabrol. Bioorg. Med. Chem. 2012, 20, 3493-3501. [CrossRef] [PubMed]

132. Hanrahan, J.R.; Chebib, M.; Johnston, G.A. Interactions of flavonoids with ionotropic GABA receptors. Adv. Pharmacol. 2015, 72, 189-200. [CrossRef] [PubMed]

133. Jäger, A.K.; Saaby, L. Flavonoids and the CNS. Molecules 2011, 16, 1471-1485. [CrossRef] [PubMed]

134. Tsuchiya, H. Structure-dependent membrane interaction of flavonoids associated with their bioactivity. Food Chem. 2010, 120, 1089-1096. [CrossRef]

135. Margina, D.; Llie, M.; Manda, G.; Neagoe, I.; Mocanu, M.; Ionescu, D.; Gradinaru, D.; Ganea, C. Quercetin and epigallocatechin gallate effects on the cell membranes biophysical properties correlate with their antioxidant potential. Gen. Physiol. Biophys. 2012, 31, 47-55. [CrossRef] [PubMed]

136. Wu, T.; He, M.; Zang, X.; Zhou, Y.; Qiu, T.; Pan, S.; Xu, X. A structure-activity relationship study of flavonoids as inhibitors of E. coli by membrane interaction effect. Biochim. Biophys. Acta 2013, 1828, 2751-2756. [CrossRef] [PubMed]

137. Tsuchiya, H.; Mizogami, M. Plant components exhibit pharmacological activities and drug interactions by acting on lipid membranes. Pharmacog. Commun. 2012, 2, 58-71. [CrossRef] 
138. Wang, C.F.; Gerner, P.; Schmidt, B.; Wang, S.Y.; Wang, G.K. Prolonged cutaneous analgesia in rats induced by 3-acetylaconitine as an additive. Drug Dev. Res. 2008, 69, 83-88. [CrossRef]

139. Xu, H.R.; Ji, G.X.; Wang, Q.; Li, X.N.; Gong, Y.J.; Zhang, Y.; Li, W.; Shen, T. Dose-dependent pharmacokinetics of bulleyaconitine A in rats. Pharmazie 2013, 68, 170-172. [CrossRef] [PubMed]

140. Weng, W.Y.; Xu, H.N.; Huang, J.M.; Wang, G.Q.; Shen, T.; Zhang, J.F. A pharmacokinetic study of intramuscular administration of bulleyaconitine A in healthy volunteers. Biol. Pharm. Bull. 2005, 28, 747-749. [CrossRef] [PubMed]

141. Chen, M.G.; Wang, Q.H.; Lin, Y.B.; Chen, K.L.; Lin, H.Y.; Lin, W.; Lin, Q.; Liu, F. Clinical study on epidural injected lappaconitine for post-operative analgesia. Chin. J. Integr. Med. 1996, 2, 26-29. [CrossRef]

142. Chen, M.G.; Wang, Q.H.; Lin, W.; Lin, Y.B.; Chen, K.L.; Liu, F.; Lin, Q.; Lin, H.Y.; Cai, H.D. A clinical study in epidural injection with lappaconitine compound for post-operative analgesia. Chin. J. Integr. Med. 1997, 3, 257-260. [CrossRef]

143. Friese, J.; Gleitz, J.; Gutser, U.T.; Heubach, J.F.; Matthiesen, T.; Wilffert, B.; Selve, N. Aconitum sp. alkaloids: The modulation of voltage-dependent $\mathrm{Na}^{+}$channels, toxicity and antinociceptive properties. Eur. J. Pharmacol. 1997, 337, 165-174. [CrossRef] [PubMed]

144. Movafegh, A.; Alizadeh, R.; Hajimohamadi, F.; Esfehani, F.; Nejatfar, M. Preoperative oral Passiflora incarnata reduces anxiety in ambulatory surgery patients: A double-blind, placebo-controlled study. Anesth. Analg. 2008, 106, 1728-1732. [CrossRef] [PubMed]

145. Aslanargun, P.; Cuvas, O.; Dikmen, B.; Aslan, E.; Yuksel, M.U. Passiflora incarnata Linneaus as an anxiolytic before spinal anesthesia. J. Anesth. 2012, 26, 39-44. [CrossRef] [PubMed]

146. Akhondzadeh, S.; Naghavi, H.R.; Vazirian, M.; Shayeganpour, A.; Rashidi, H.; Khani, M. Passionflower in the treatment of generalized anxiety: A pilot double-blind randomized controlled trial with oxazepam. J. Clin. Pharm. Ther. 2001, 26, 363-367. [CrossRef] [PubMed]

147. Modabbernia, A.; Akhondzadeh, S. Saffron, passionflower, valerian and sage for mental health. Psychiatr. Clin. N. Am. 2013, 36, 85-91. [CrossRef] [PubMed]

148. Mao, J.J.; Li, Q.S.; Soeller, I.; Rockwell, K.; Xie, S.X.; Amsterdam, J.D. Long-term chamomile therapy of generalized anxiety disorder: A study protocol for a randomized, double-blind, placebo-controlled trial. J. Clin. Trials 2014, 4, 188. [CrossRef]

149. Amsterdam, J.D.; Li, Y.; Soeller, I.; Rockwell, K.; Mao, J.J.; Shults, J. A randomized, double-blind, placebo-controlled trial of oral Matricaria recutita (chamomile) extract therapy for generalized anxiety disorder. J. Clin. Psychopharmacol. 2009, 29, 378-382. [CrossRef] [PubMed]

150. Wolfson, P.; Hoffmann, D.L. An investigation into the efficacy of Scutellaria lateriflora in healthy volunteers. Altern. Ther. Health Med. 2003, 9, 74-78. [PubMed]

151. Gao, J.; Sanchez-Medina, A.; Pendry, B.A.; Hughes, M.J.; Webb, G.P.; Corcoran, O. Validation of a HPLC method for flavonoid biomarkers in skullcap (Scutellaria) and its use to illustrate wide variability in the quality of commercial tinctures. J. Pharm. Pharm. Sci. 2008, 11, 77-87. [CrossRef] [PubMed]

152. Yun, I.; Cho, E.S.; Jang, H.O.; Kim, U.K.; Choi, C.H.; Chung, I.K.; Kim, I.S.; Wood, W.G. Amphiphilic effects of local anesthetics on rotational mobility in neuronal and model membranes. Biochim. Biophys. Acta 2002, 1564, 123-132. [CrossRef] [PubMed]

153. Kopeć, W.; Telenius, J.; Khandelia, H. Molecular dynamics simulations of the interactions of medicinal plant extracts and drugs with lipid bilayer membranes. FEBS J. 2013, 280, 2785-2805. [CrossRef] [PubMed]

154. Di Meo, F.; Fabre, G.; Berka, K.; Ossman, T.; Chantemargue, B.; Paloncýová, M.; Marquet, P.; Otyepka, M.; Trouillas, P. In silico pharmacology: Drug membrane partitioning and crossing. Pharmacol. Res. 2016, 111, 471-486. [CrossRef] [PubMed]

155. Williamson, E.M. Synergy and other interactions in phytomedicines. Phytomedicine 2001, 8, 401-409. [CrossRef] [PubMed]

(C) 2017 by the author. Licensee MDPI, Basel, Switzerland. This article is an open access article distributed under the terms and conditions of the Creative Commons Attribution (CC BY) license (http:/ / creativecommons.org/licenses/by/4.0/). 